\author{
NBER WORKING PAPER SERIES \\ ON \\ HISTORICAL FACTORS IN LONG RUN GROWTH
}

\title{
SHARE LIQUIDITY AND INDUSTRIAL GROWTH \\ IN AN EMERGING MARKET: \\ THE CASE OF NEW ENGLAND, 1854-1897
}

Peter L. Rousseau

Historical Paper 117

NATIONAL BUREAU OF ECONOMIC RESEARCH

1050 Massachusetts Avenue

Cambridge, MA 02138

February 1999

The author thanks participants at the November 1998 meetings of the Social Science History Association for helpful comments. Any opinions expressed are those of the authors and not those of the National Bureau of Economic Research.

(C) 1999 by Peter L. Rousseau. All rights reserved. Short sections of text, not to exceed two paragraphs, may be quoted without explicit permission provided that full credit, including (C) notice, is given to the source. 
Share Liquidity and Industrial Growth in an Emerging Market:

The Case of New England, 1854-1897

Peter L. Rousseau

NBER Historical Paper No. 117

March 1999

Development of the American Economy

JEL No: E44, N11, N21

\section{ABSTRACT}

The rapid growth of equity markets in emerging economies over the past decade has prompted economists to raise important questions about their macroeconomic impact. Although the relative brevity of this expansion has made it challenging to perform such an evaluation, there remains a strong notion that liquidity promotes participation in equity markets and is thus central to their deepening. Interestingly, the first U.S. market for industrial equities arose in Boston more than 150 years ago, when capital flows were considerably less volatile than those associated with today's emerging markets. This difference makes it possible to gain insights about the long-run effects of growing sophistication in equity markets by studying the full period of Boston's emergence. From primary sources hitherto unused for scholarly investigations, namely the running annual worksheets of securities price fluctuations which underlie Boston broker Joseph Martin's volumes on the history of the Boston stock market, this paper formulates and presents broad-based indices of annual prices and returns for banking and industrial equities traded from 1854 to 1897 , as well as measures of overall market capitalization in these sectors. A set of vector autoregressive models then relates increases in liquidity, as measured by the falling par values of industrial shares, to rising prices and capitalizations of firms traded in the Boston market. Increases in liquidity and the real market value of equity capital in banks and industrials are also linked to higher annual earnings among the region's industrial workers. The results support the view that share liquidity was a key factor in the rise of the U.S. as a classic case of finance-led industrialization.

Peter L. Rousseau

Department of Economics

Vanderbilt University

Box 1819 Station B

Nashville, TN 37235

and NBER

peter.1.rousseau@vanderbilt.edu 
Recent financial crises in the emerging markets of East Asia, Latin America and Eastern Europe have heightened the urgency of policy debates aimed at evaluating the macroeconomic impact of equity markets and any complementarities which they may share with more traditional financial intermediaries such as banks. The task is a formidable one in the context of emerging markets, however, since the impact of an equity market appears to depend as much on the web of capital controls, exchange rate policies and banking practices that characterize individual economies as on the structural and regulatory features of their stock exchanges. For example, the liquidity provided by equity markets could in the presence of an unsustainable exchange rate peg and freely-moving capital actually exacerbate the instability of international capital flows (Radelet and Sachs, 1998). Nevertheless, there remains a strong belief among many macro economists that well-functioning equity markets can raise long-term growth rates by mobilizing savings and improving the efficiency with which resources are delivered to productive uses (see, for example, Levine and Zervos, 1998; Rousseau and Wachtel 1998a).

Given the valuable insights that past experience can often provide for current policy, it is perhaps surprising that the U.S. in the nineteenth century has only recently seen renewed interest as a case of growth sparked by emerging financial markets (Sylla, 1998; Rousseau, 1998; Rousseau and Wachtel, 1998b). ${ }^{1}$ In this paper, recently-uncovered information from primary sources about the first U.S. market for industrial equities in Boston between 1854 and 1897 offers a unique opportunity to explore the impact of an emerging equity market on economic conditions in the nation's then foremost industrial region. The historical lens offers an important advantage in that capital flows across regional and national boundaries

\footnotetext{
${ }^{1}$ The link between financial factors and the real economy was proposed by Joseph Schumpeter in 1911, and was later developed more formally by Gurley and Shaw (1955), Goldsmith (1969), McKinnon (1973), and Shaw (1973), to whom most of the new literature owes its underpinnings. In the context of U.S. financial history, Davis (1965), Sylla (1969), and James (1978) describe the formation of a national capital market via commercial paper and its role in fueling the nation's rapid industrialization.
} 
were considerably less volatile in New England during the second half of the nineteenth century than those which we associate with emerging markets today. This allows attention to focus on liquidity and its role in promoting the development of a specialized yet integrated capital market. Moreover, even though a national market for government securities and several local markets for the equity shares of banks and insurance companies emerged early in the nation's history and appear to have laid the foundation for the period of vigorous growth that had certainly begun by 1840 (Sylla ,1998), New England was the only region in which a market for industrial equities arose to complement bank financing prior to 1850 (Atack and Rousseau, 1999). These industrials traded in Boston at public auctions as early as 1817 and on a formal stock exchange after 1834, but their market (as well as that for bank equities) thickened considerably in the 1850s. This places Boston's market more than fifty years ahead of the industrial market in New York that Navin and Sears (1955) describe.

One problem commented upon by dealers and brokers in the early days of the Boston stock market and described by Martin (1856) was that high par values of industrial equities (usually \$1000) limited demand for these securities by placing some potentially interested and willing savers outside of their budget constraints at a time when per capita incomes ranged from $\$ 100$ to $\$ 300$ per annum. This study suggests that decreases in the average par values of traded industrial shares that occurred between 1854 and 1897 eased these participation constraints and increased the liquidity of an increasingly sophisticated market in banking and industrial equities. The deepening of the long-term capital market which accompanied these structural changes also appears to have facilitated the well-documented shift by banks from an emphasis on medium-term lending based on personal connections (see Lamoreaux, 1986, 1994; Dalzell, 1987) to the safer and more professionally managed loans for short-term working capital via commercial paper described by Davis (1960). In all, the evidence, which derives from a set of vector autoregressive (VAR) models, supports the notion that the eventual segmentation of the short- and long- 
term capital markets improved the efficiency of resource allocations to industry by reducing mismatch, raised share prices, and promoted an expansion of banking, all of which had measurable effects on the annual incomes of industrial workers. ${ }^{2}$

The paper is organized as follows. Section I describes features which characterize the equity market in Boston between 1854 and 1897, presents new indices of price and total return performance for banking and industrial shares, and documents the growth in market size and liquidity. Section II discusses the annual measures of regional economic performance that are available continuously over the time period of the study. Section III discusses testable hypotheses which emerge from the graphical analysis in Section I, outlines a methodology for their formal investigation, and presents the empirical findings. Section IV concludes.

\section{The Performance of the Boston Stock Market, 1854-1897.}

\section{A. The Availability of Stock Market Data}

Until recently, relatively little was known about the nation's premier market for industrial securities. The most comprehensive record of trading covering the formal exchange from its inception appears in a series of volumes by Joseph G. Martin (1856; 1871; 1898). Martin was a Boston broker who also organized information on equity market activity for sale in various forms to local newspapers, other brokers, and potential investors starting in the early 1850s. These volumes contain par values, dividends,

\footnotetext{
${ }^{2}$ The path of finance-led industrialization in New England after 1850 may not, however, have been optimal. Lamoreaux (1994), for example, emphasizes the decline of "insider lending" by banks after the Civil War and presents evidence that safer lending practices may have suppressed new and innovative projects. This is because loans to business interests closely connected to individual bank directors helped depositors and smaller equity holders to cope with informational frictions rather than serving as a source of moral hazard which is the way in which such activities are viewed today. To the extent that a thickening equity market was able to promote the long-term financing of industrial enterprises (albeit primarily large ones) and an expansion of banking resources despite some suppression of innovative ideas, my results suggest that the effects of market liquidity in a more modern setting may be even more dramatic.
} 
authorized capital, and annual high and low stock prices in each calendar year from 1835 to 1898 for banks, insurance companies, railroads and industrials. ${ }^{3}$ Atack and Rousseau (1999) have analyzed these data for banks and industrials between 1835 and 1869 and have verified their reliability by cross-checking prices with those reported in other sources such as the Boston Daily Advertiser, the Boston Statesman, the Boston Evening Transcript, and Hunt's Merchants' Magazine. Their analysis reveals several characteristics of the equity market that are particularly important for this study. First, price movements were an important source of fluctuations in total returns, a view which contrasts with that of Baskin (1988), who suggested that steady prices and dividend streams led equities in the nineteenth century to function essentially like bonds in a regime of stable interest rates. Second, the market for banking and industrial shares in Boston was a decentralized one. Even though the formal exchange (called the "Broker's Board") was established in 1834 to focus the liquidity of the market in a single location for twice-daily calls, shares in most firms were also actively traded at public auctions conducted by local securities dealers. ${ }^{4}$ Finally, given the many auctions that were regularly announced in local newspapers, it appears that the actual transactions which occurred in a significant subset went unreported in the press. ${ }^{5}$

\footnotetext{
${ }^{3}$ Martin obtained price and dividend quotes for the1835-1850 period from records of the exchange's founding member P. P. F. DeGrand and auctioneer Stephen J. Brown.

${ }^{4}$ Several members of the Board officiated as auctioneers in the early days of the exchange. As this was judged to interfere with the business of the Board, however, it was ruled in March 1848 that with the exceptions of estate transactions and cases of special permission "any member of the Board who shall attend a public sale of stocks, or who shall, directly or indirectly, buy or sell at such sale, shall vacate his seat at the Board" (Martin, 1856). The rule seems to have had little effect on the extent of auction trading in industrials. In 1854, for example, Martin (whose year-end summary of equity trades in the Boston market was reported in the January 10, 1855 edition of the Boston Daily Advertiser) reports that 41 industrials were quoted at the Board and 2,237 shares changed hands in that market during the year. My own analysis of all issues of the Boston Daily Advertiser in 1854 uncovered off-exchange trades of 702 additional industrial shares, including several issues that were inactive at the Board. A formal analysis of auctions in this market and their continued importance despite rapid growth of the stock exchange is a topic in which this author is actively engaged.

${ }^{5}$ For example, the Boston Daily Advertiser in 1854 regularly announced stock auctions by dealers N. Thompson, S. Brown, Dupee and Perkins, Hayward and Dorr, and Brewster, Sweet and Co., yet reported
} 
The decentralized nature of the industrial market makes the construction of a continuous and accurate picture of prices and trading volumes prior to 1900 from newspapers and the exchange's "Official Report" virtually impossible. In fact, the relative thinness of the industrial market ${ }^{6}$ appears to have made the preference of investors to trade these shares at auction on Wednesdays and Saturdays even stronger as the century progressed, with the auction market for industrials (and banks) completely eclipsing the formal exchange by $1886 .^{7}$ As a result of these problems, previous researchers including Knowlton

results from only the first two. Results of auctions which did appear in the Boston Daily Advertiser and the Boston Evening Transcript were often compiled by Martin himself. Indeed, it appears that the gathering, reporting and selling of financial information were among the central activities of his State Street brokerage.

${ }^{6}$ To observe that nineteenth century industrial markets were relatively thin by no means implies that they were inactive. Though volume records that include trades both at the exchange and at auction are generally unavailable, some information about the extent of share turnover can be gained from the transfer books of several of the larger manufacturing firms. My examination of these handwritten records, which are on deposit in the Historical Collections Department of the Baker Memorial Library at the Harvard School of Business Administration (Mss: 442), indicate that on average 11.5 percent (172 shares of par $\$ 1000$ ) of the outstanding stock in the Lawrence Manufacturing Company officially changed hands annually between 1854 and 1897 . These figures were 15.3 percent (245 shares with par $\$ 1000$ before 1870 and 330 shares with par $\$ 500$ between 1870 and 1891) for the Dwight Manufacturing Company and 20.6 percent (428 shares with par $\$ 500$ between 1854 and 1880) for the Pepperell Manufacturing Company. A transfer was usually recorded on the company books when the new shareholder first appeared at the Boston office to claim a dividend. Since some transfers were estate distributions to relatives which did not pass through an organized market and others represented shares which may have traded several times between semiannual dividends (see Abbot Lawrence Lowell and Francis Cabot Lowell, 1884), these figures are only suggestive of actual activity in the organized equity market.

${ }^{7}$ The twice-weekly auction calls were presumably the most efficient mechanism for pricing shares and focusing liquidity in the industrial market. Indeed, by the time that the exchange adopted continuous trading in 1885 (Boston Stock Exchange, 1930, p. 15), nearly all trades in banks and industrials were made at auction. In fact, the transaction records of Boston brokers Foote and French show only 26 transactions in industrial equities and no transactions in bank equities on the stock exchange between March and October of 1881. To allow brokers to engage in the burgeoning auction market, industrials were removed as an official "department" of the exchange on March 1, 1886 and no longer appeared on the "Official Report," although written records of quotations recorded by the clerk of the exchange indicate that industrial stocks continued to be called (Mss. 785, Historical Collections Department, Baker Library). This is because the Constitution of the exchange had by this time been modified to state that "any member who shall be connected directly or by a partner with any organization in the city of Boston which permits dealings in any securities or other property admitted to dealing in any department of this Exchange, shall be liable to suspension or expulsion as the Governing Committee may determine" (Boston Stock 
(1948), McGouldrick (1968), Cudd (1974), and Fenstermaker et. al. (1988) have relied exclusively on Martin's published annual highs and lows for share prices in the Boston market.

However, I have recently uncovered the supporting worksheets which Martin compiled on an annual basis for sale to local investors which contain end-of-quarter prices as well as quarterly high and low prices for all securities traded in the Boston market from 1854 to 1901. This surprisingly modern level of detail exceeds that of any other source which has been compiled for a U.S. equity market in the midnineteenth century. ${ }^{8}$ The worksheets, which are on deposit at the Baker Memorial Library at the Harvard School of Business Administration and have been hitherto unused for scholarly investigations, even achieved a degree of official recognition at the time of their regular publication. ${ }^{9}$ Importantly, they include prices which were realized at public auctions as well as quotations on the formal exchange. In addition, the worksheets offer a key advantage for building measures of market performance over the use of annual high and low prices - the well-defined holding periods over which prices and dividends are reported eliminate distortions which would otherwise appear in derived price and return indices due to the mixing of observations that are likely to be unsynchronized. ${ }^{10}$ The first order autocorrelation which is introduced to stock price indices by the technique of averaging periodic highs and lows (see Snowden, 1990) is also absent by construction. The precise timing of observations permits a more thorough analysis of fluctuations

Exchange, 1915, p. 35). In contrast, the Boston Evening Transcript reported that 93 bank shares and 91 industrial shares changed hands in the two auctions which were covered by the paper on Saturday, January 2,1886 alone. These auction volumes were not atypical and persisted from the late 1860 s through the turn of the century.

${ }^{8}$ For example, the indices prepared by Alfred Cowles and Associates in their 1938 study of the New York Stock Exchange begin only in 1871 and use the average of monthly high and low prices.

${ }^{9}$ These worksheets were available to contemporary investors on an annual basis between issues of Martin's summary volumes, and were deposited with the District Court of Massachusetts prior to 1862 and the Library of Congress thereafter.

${ }^{10}$ Indices constructed with annual highs or lows have components of price appreciation whose durations can range from a single day to 729 days. 
in prices and returns for equities traded in the early Boston market than has been previously possible and facilitates the statistical investigation of timing relationships between market deepening and regional economic growth.

\section{B. Measures of Price and Return Performance of Traded Banks and Industrials}

Figures 1 and 2 present indices of price performance for traded banks and industrial firms on or about January 1 of each year from 1854 to 1897 . Periods of cyclical contraction as defined by the National Bureau of Economic Research are shaded. The indices weight firms by their shares in the total market capitalization of their respective sectors, with market capitalization for each firm given by the product of share price and the number of authorized shares. ${ }^{11}$ Table A1 of the Appendix lists these series. ${ }^{12}$

Bank stock prices rose by 43 percent in nominal terms between 1862 and 1875 before falling by 20 percent over the three years of general price deflation and investor uncertainty that preceded the successful resumption of gold payments in 1879 . They returned to their 1877 levels shortly after resumption, appreciated very little in the 1880 s, and fell by 14 percent from 1890 to 1897 . Using the index of consumer prices published by the Bureau of Labor Statistics (BLS) as a deflator, ${ }^{13}$ real bank stock prices fell by 39 percent between 1854 and 1865 before nearly doubling in the course of a vigorous and prolonged

\footnotetext{
${ }^{11}$ In a given year, the indices include firms with observations on January 1 of both the current year and the previous one. The weighted sum of the percentage changes in price for the included firms then serves as a multiplier to update the preceding index number. The indices use 100 as the base value in 1854 . This "chaining" technique resembles that used by Cowles and Associates (1938).

12 Table A1 also includes price indices with firms weighted by their book capitalizations. Since these series correspond very closely to those in Figures 1 and 2 and market value is more representative of a firm's sectoral importance than book value, the discussion in this section and my subsequent empirical work refer exclusively to the market-weighted indices.

${ }^{13}$ The real price indices are for comparison only, since the BLS index (U.S. Bureau of the Census 1975, series E135) summarizes "retail prices of goods and services bought by city wage earners and clerical workers" and can thus capture at best only broad trends in consumer prices. Nevertheless, it is the most commonly-used price index for the period among several which differ considerably in both construction and time patterns.
} 


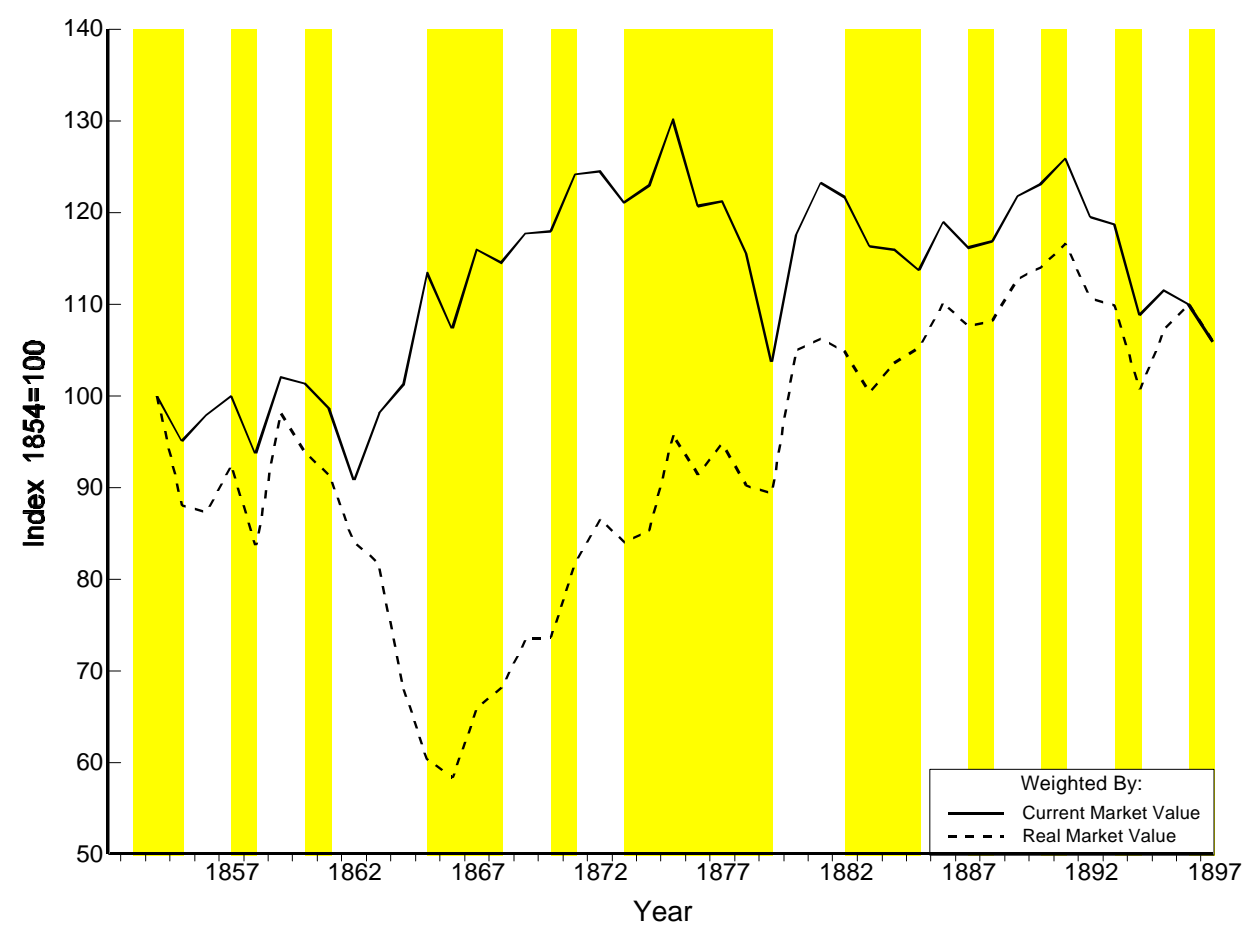

Figure 1. Bank Stock Price Indices

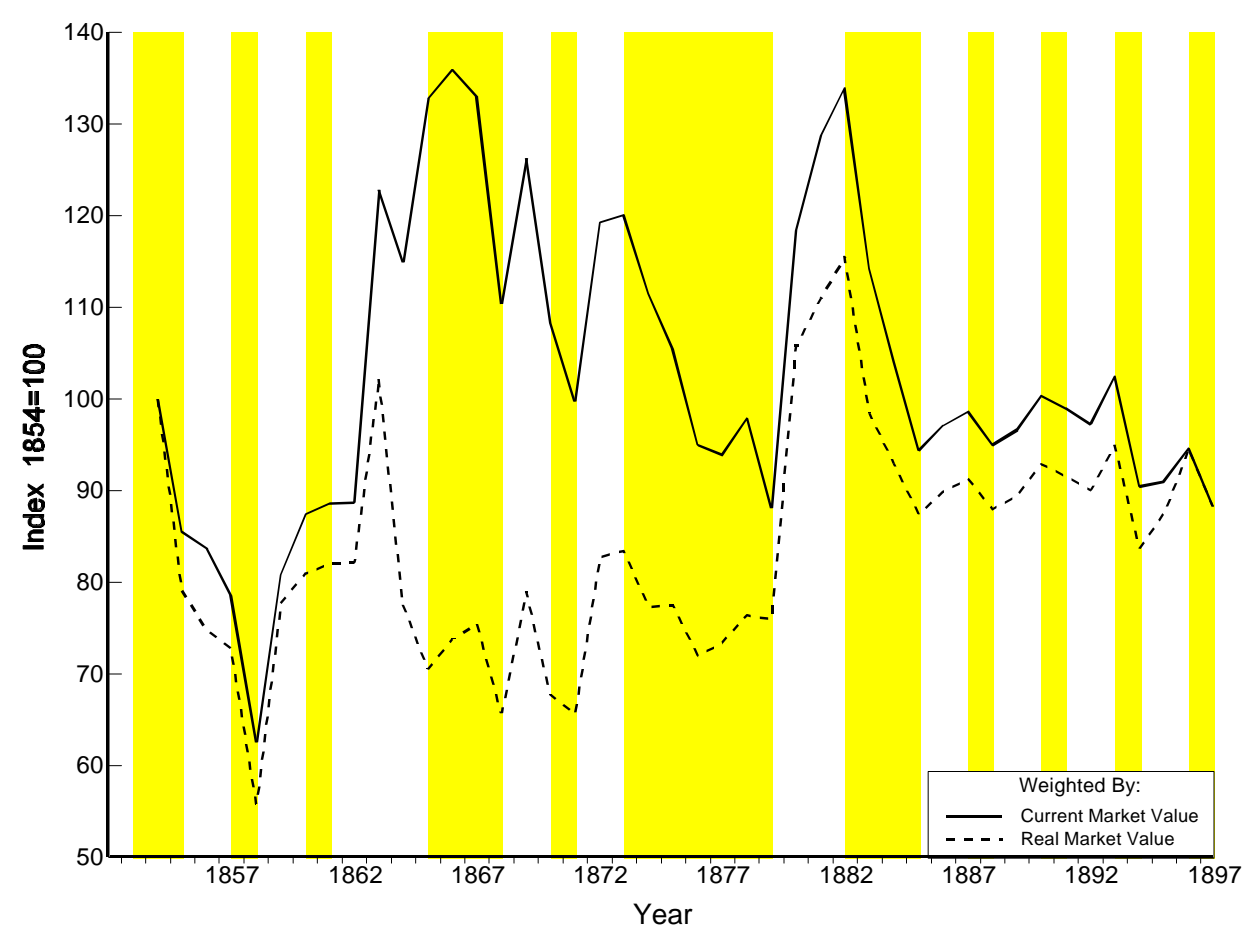

Figure 2. Industrial Stock Price Indices 


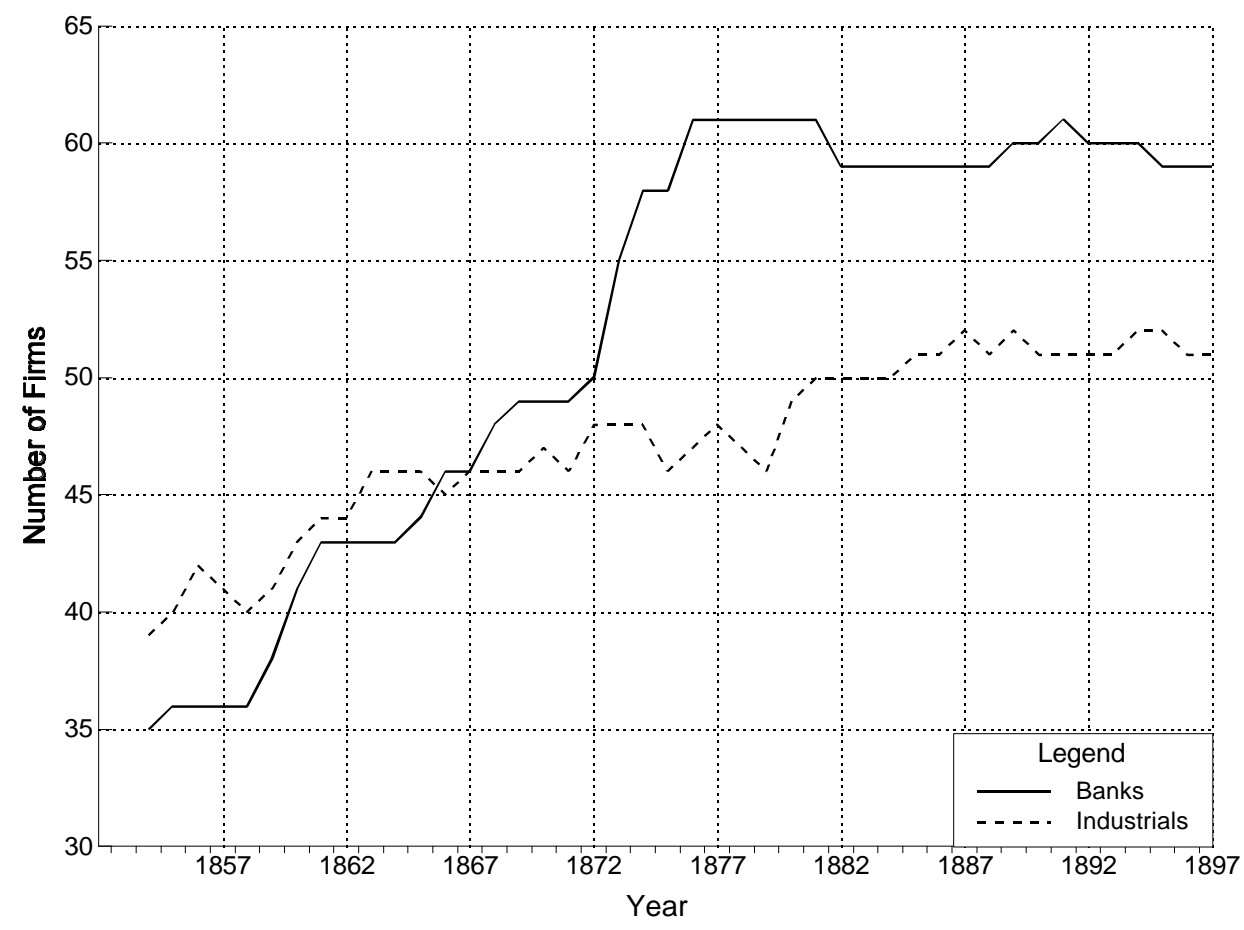

Figure 3. Firm Coverage of Price Indices

rise from 1866 to $1891 .{ }^{14}$ Declines in bank stock prices also appear to lead the business cycle in seven of the ten downturns that occur over the sample period. Industrials experienced wider price fluctuations, with the index rising by 116 percent between 1858 and 1867 . The appreciation is smaller but more prolonged in real terms, with prices rising 102 percent between 1858 and 1882 before falling 24 percent by 1885 . Fluctuations in industrial prices match the NBER reference cycles quite closely, especially after 1860. Since the pre-1900 reference dates were constructed from a set of series in which industrial activity is strongly represented (Burns and Mitchell 1946, Table 17, p. 82), it is reassuring that these independent estimates are mutually supportive.

${ }^{14}$ The decline of ex-post real bank prices during the Civil War was largely the result of an enormous and largely unanticipated increase in the supply of currency that accompanied a heightening of the Union's war efforts. It is nonetheless interesting that thirteen banks paid extra dividends in excess of 25 percent in 1865 in the wake of their conversion to national charters, with the Suffolk Bank even declaring an extra dividend of 168 percent in January! 
The number of firms included in the price indices for banks (Figure 3) rises rapidly from 35 in 1854 to 61 by 1876 . It remains relatively steady thereafter, with 59 banks included in 1897, which was the eve of a flurry in merger activity. Coverage for the industrial price indices rises from 39 firms in 1854 to 48 by 1872 and remains steady until 1879 . The number then increases to 52 by 1887 and ends with 51 firms in 1897. The observation that periods during which the prices of both banking and industrial equities exhibited their strongest advances coincided with periods of rapid growth in the number of listed firms is particularly striking, and may well reflect the types of price effects that are often associated with a deepening equity market.

Value-weighted annual returns to bank shareholders (Figure 4) are usually positive and become visibly smaller and less variable after $1879 .{ }^{15}$ Industrials (Figure 5) offered investors higher but much more variable returns which also fall in level and variability around $1880 .{ }^{16}$ The fall in bank returns after 1879 is consistent with a tightening of competitive pressures in the wake of rapid growth in the number of banks over the preceding two decades, but the lower variability of both banking and industrial stocks may also reflect a deepening, increasingly specialized and more liquid capital market. In particular, the less-risky portfolios that accompanied more professional lending practices earned lower returns which investors accepted in exchange for less variability. At the same time, an expanding market for industrials shifted the provision of long-term finance away from banks and into directly-held instruments which had

${ }^{15}$ Bank returns average 8.4 percent through 1879 and 3.9 percent thereafter with standard deviations of 6.8 percent and 3.5 percent in these sub-periods. Ex-post real returns (deflated with BLS inflation rates) average 8.1 percent through 1879 and 4.6 percent thereafter, with respective standard deviations of 9.3 percent and 3.8 percent.

${ }^{16}$ Industrial returns average 10.7 percent through 1879 and 3.6 percent thereafter with respective standard deviations of 16.9 percent and 7.2 percent. Real returns fall from 10.1 percent to 4.4 percent across the sub-periods, with standard deviations decreasing from 15.2 percent to 6.7 percent. 


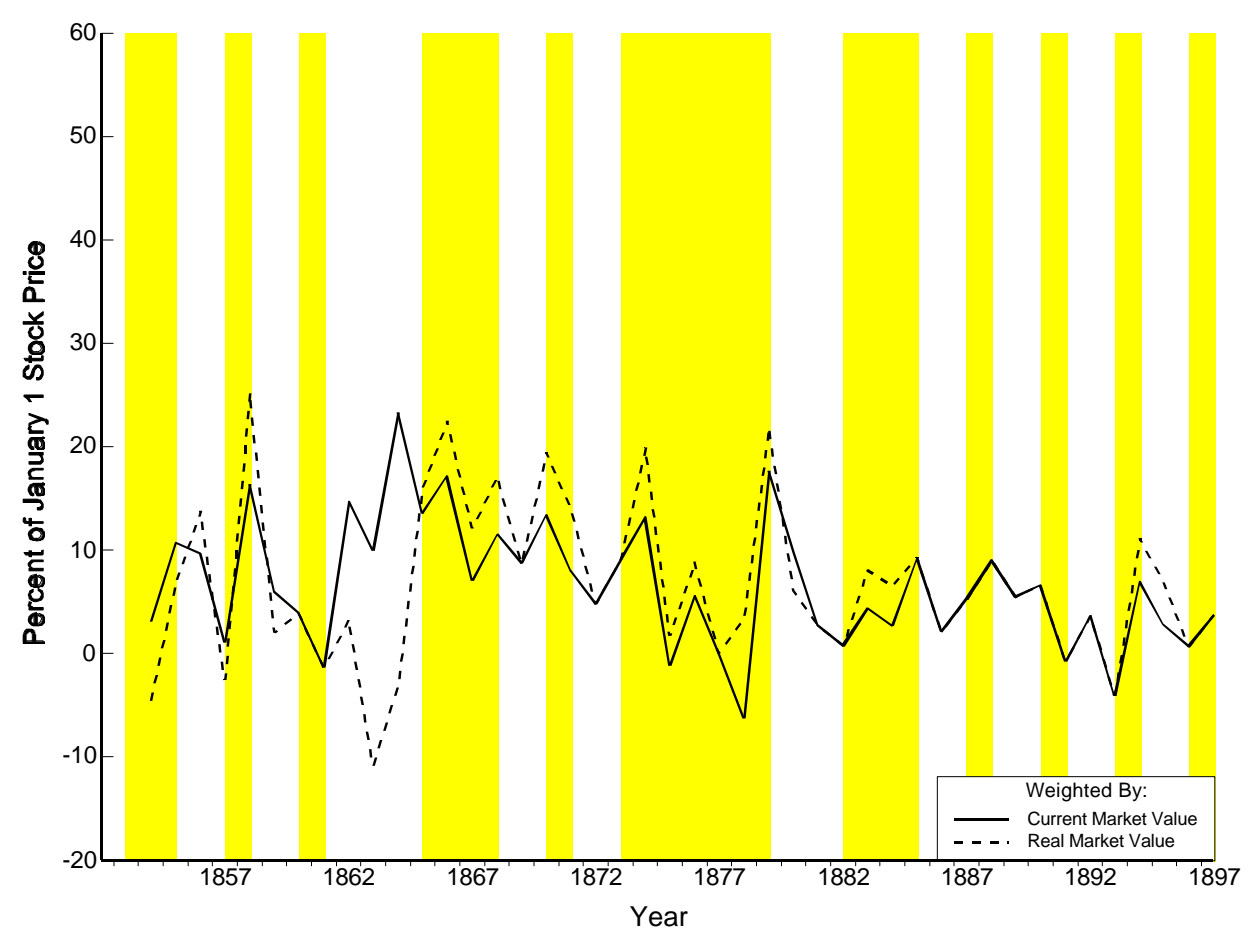

Figure 4. Total Returns For Traded Bank Stocks

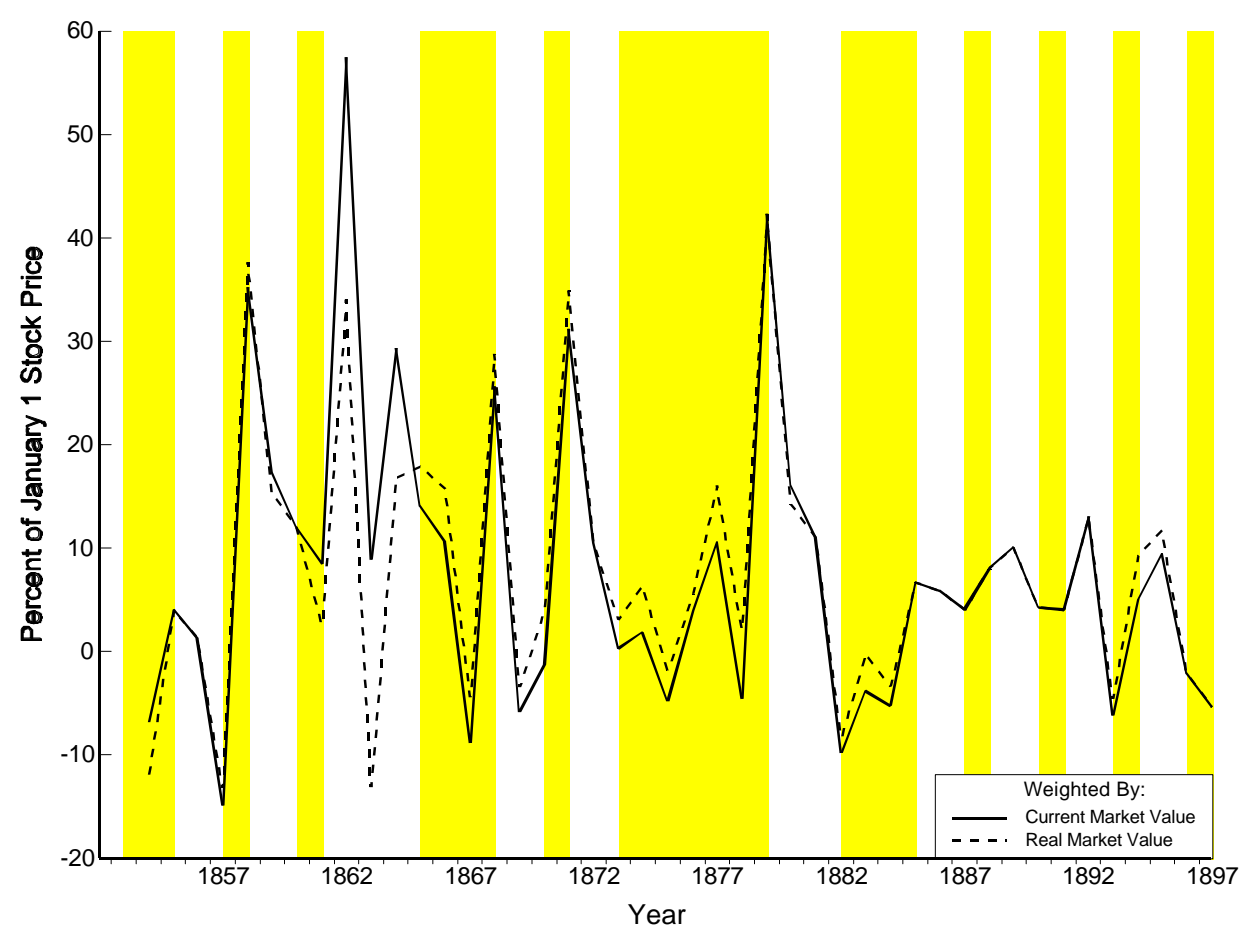

Figure 5. Total Returns For Traded Industrial Stocks 


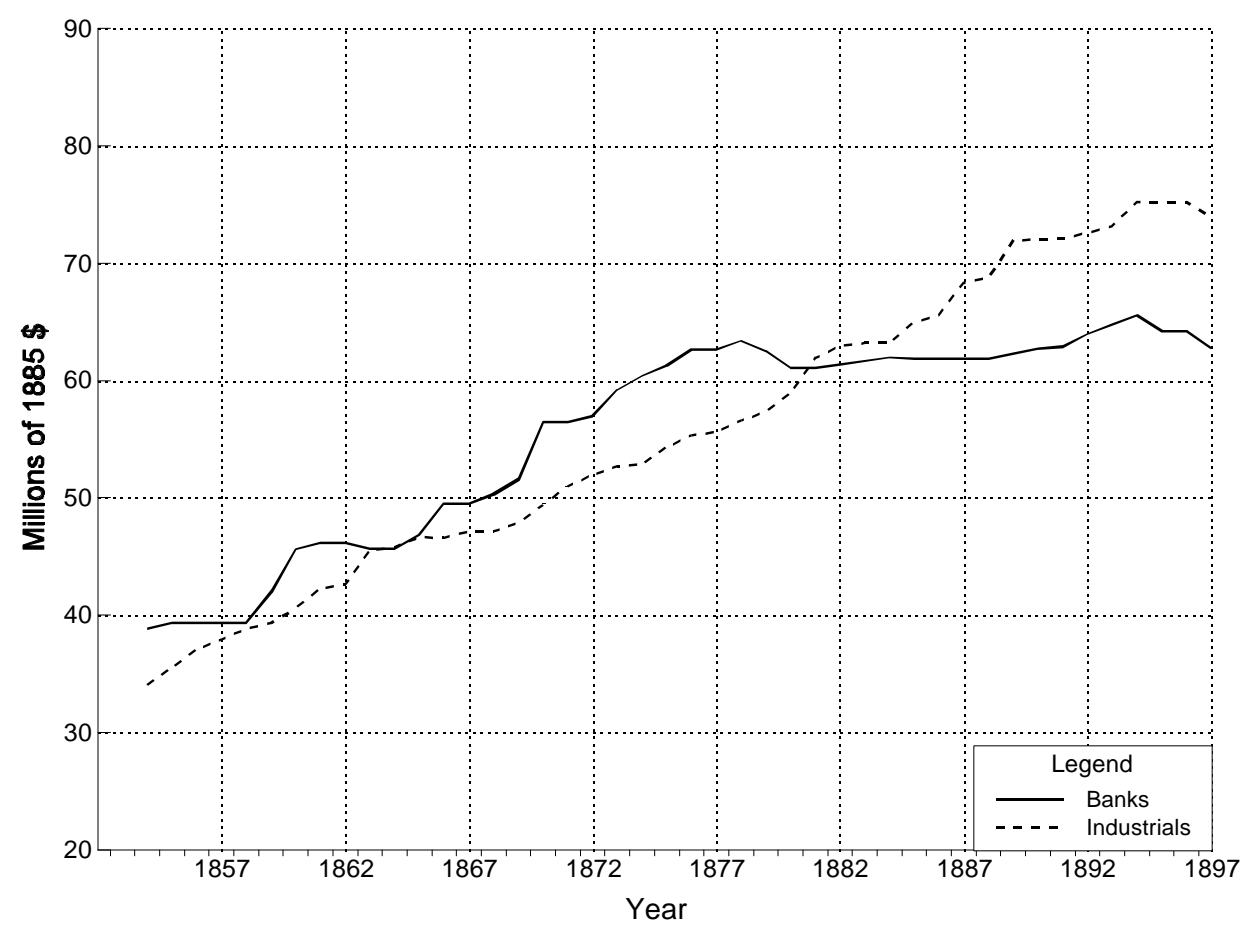

Figure 6. Share Price-Adjusted Stock Market Capitalization

become accessible to an increasing subset of New England savers. ${ }^{17}$

\section{Measures of Market Size and Liquidity}

The growth in the real value of equity capital that occurred in Boston for traded banks and industrial firms (Figure 6), especially prior to 1880, reflects rapid market deepening. These measures use the price indices weighted by market value (Figures 1 and 2) to deflate the product of price and quantity for all outstanding shares to reflect 1885 share prices. The "share price-adjusted" measures of market size have several advantages over the available alternatives. For example, the total of authorized capital neglects depreciation and the growth of internal equity, and would weight all infusions of fresh capital

${ }^{17}$ Movements along a risk-return tradeoff, however, were clearly not the only reasons for the decline in industrial returns. New England also faced increasing competition in the provision of cloth and demand for the cotton crop from the Southern and mid-Atlantic states, especially after 1880 (see Copeland, 1917). 
identically regardless of their timing. Alternatively, the nominal market value of shares takes much of its year-to-year variation from price movements which reflect inflation and temporary deviations from the long-run supply and demand for shares. Choosing a general index of consumer prices (such as the BLS) to deflate market value would at best neglect the effects of these deviations. For these reasons, the share price-adjusted measures of capitalization are used in the empirical analysis which follows in Section III.

The real market capitalization of traded industrials doubles between 1854 and $1897,{ }^{18}$ with continued advances after 1880 despite returns which were lower and more variable. Bank capitalization advances by 62 percent in real terms between 1854 and 1878 and rises very little thereafter. ${ }^{19}$ The period of sharp increase in bank capitalization coincides with that of rapid appreciation in stock prices (Figure 1).

Earlier studies of manufacturing in New England (e.g., Knowlton, 1948; McGouldrick, 1968; Atack and Rousseau, 1999) have noted the high par values attached to industrial equities early in the nineteenth century and the participation constraints that they implied. The high par values presumably helped to concentrate firm ownership and control, shielded shares from speculation, and reduced the costs of maintaining transfer books. What these studies do not emphasize, however, is a general and marked decline in par values that began in the 1850 s and continued through 1900 . Both new entry and markdowns of existing par values by stock splits account for this decline prior to 1870 . For example, 11 of the 35 industrial firms with continuous price listings between 1854 and 1870 lowered their par value at least once,

${ }^{18}$ Here and henceforth, the term "real market capitalization" refers to deflation by 1885 share prices.

${ }^{19}$ The lack of growth in the market capitalization of banks after 1879 again suggests market saturation. The continued advance of deposits, however, does not imply stagnation in the sector. In fact, using the BLS price index as deflator, individual deposits in traded banks rose by an average annual rate of 4.6 percent between 1880 and 1897 (U.S. Comptroller of the Currency, various issues). This was a considerable decline from the annual growth of 6.9 percent recorded between 1865 and 1879, but does imply a continued expansion of banking activities. Overall, real individual deposits rose from about half to nearly double the amount of real bank capital between 1865 and 1897, with 57 percent of the total increase of $\$ 109$ million occurring after 1879 . 
with seven of these cases involving firms with par values of $\$ 1000$ in 1854 . The average par value of the 12 firms which became listed between 1854 and 1870 was $\$ 258$. Entry was a more important factor after 1870 , with only three firms lowering their par values but an average par value of $\$ 190$ for the 10 firms which entered between 1871 and 1897.

The fall in par values allowed more individuals to participate in the market and pick from a wider selection of industrials. As such, it provided investors with more potential matches for conducting asset exchanges, and thereby increased the liquidity of their holdings. Since a liquid market should value an otherwise identical security more highly than an illiquid one, increases in liquidity also encouraged firms to raise funds through the long-term equity market in which organized trading was possible. Figure 7 shows the number of shares per $\$ 1000$ of authorized capital on or around January 1 for all traded industrial firms, which should vary directly with liquidity. ${ }^{20}$ Indeed, this measure rises by 88 percent between 1854 and 1876, and gains an additional 25 percent of its 1854 value between 1877 and 1897. Since bank stocks generally had fixed par values of $\$ 100$, information about their liquidity cannot be inferred in this way; nevertheless, it is likely that liquidity in the market for industrials also reflected increases in the liquidity of bank stocks, since both types of equities traded predominantly at the same public auctions. I return to this point in Section III.

The gradual nature of the rise in the number of shares per $\$ 1000$ of authorized capital is noteworthy, and is likely to reflect tradeoffs faced by the principal owners of New England's manufacturing interests between losses in corporate control and the potential for higher market values that

${ }^{20}$ In empirical studies of modern equity markets and their effects on economic growth, Levine and Zervos (1998) and Rousseau and Wachtel (1998a) use the total market value of actual equity trades or the ratio of this value to total market capitalization (also called "turnover") as proxies for liquidity. Even measures of transaction volume, however, suffer from conceptual weaknesses in that liquidity affects market values and entry even among those who are ultimately unable or unwilling to use the formal mechanism. In other words, the volume of trades may not well reflect market accessibility. 


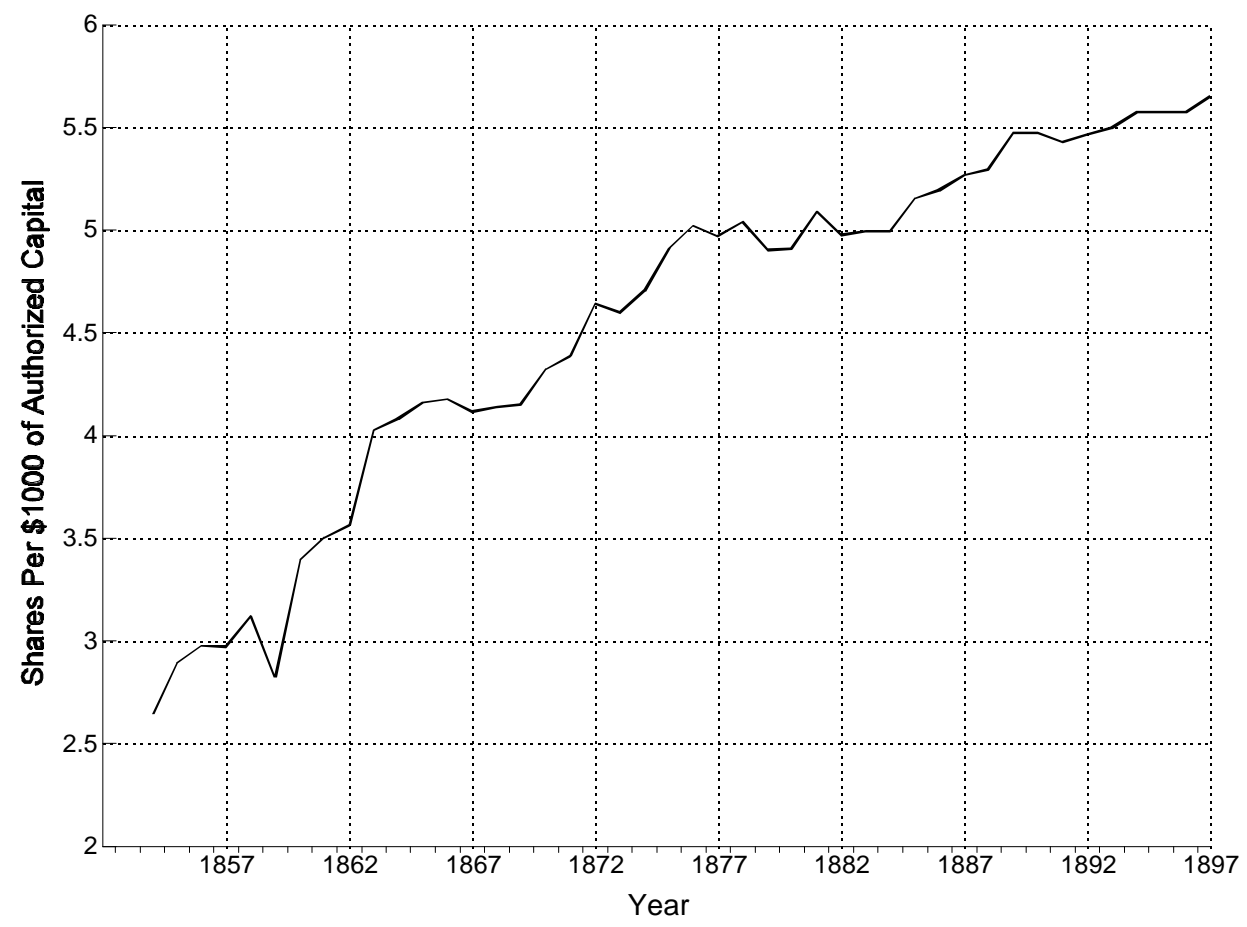

Figure 7. Shares Per $\$ 1000$ of Authorized Industrial Capital

accompanied the reduction of par values and active use of the equity market. The severity of these tradeoffs differed across firms according to their structural and financial characteristics. Thus, par values gradually fell as the benefits of wider ownership became increasingly apparent. It was these types of frictions, which persist to the present day in the U.S. equity market but are less commonly manifested in extraordinarily high share prices ${ }^{21}$, that restrained owners of nineteenth-century industrial firms from lowering the par values of their shares through frequent stock splits, thereby permitting an examination of changes in industrial growth which accompanied the gradual shift.

It is not possible to verify from the surviving company records whether participation constraints

${ }^{21}$ The Berkshire-Hathaway company, whose closely-held nature is ensured by a share price of about $\$ 70,000$, is one (perhaps extreme) example of the continued prevalence of generally high share prices in the U.S. equity market. 
became less binding for all listed firms as the market for industrial equities emerged. Nevertheless, key information about the growing diffusion of share ownership can be obtained for a subset of firms from their dividend records. In particular, the number of dividend checks claimed after a declaration should closely reflect the number of shareholders in a given firm. ${ }^{22}$ Figure 8 plots this number for the first dividend in each calendar year in which records are available for the Dwight, Lawrence, Lyman, Massachusetts Cotton and Pepperell Manufacturing Companies. The gaps in the individual series reflect missed dividends. The handwritten records from which I derived these figures are on deposit in the Historical Collections Department of the Baker Memorial Library (Mss: 442). Four of the five firms show a marked increase in the number of shareholders, with ownership nearly tripling for the Pepperell Manufacturing Company between 1860 and 1897, doubling for Lyman Mills between 1854 and 1897, and rising by 60 percent for Massachusetts Cotton Mills between 1854 and 1897 and 47 percent for the Dwight Manufacturing Company between 1863 and 1897. ${ }^{23}$ Pepperell, Lyman, and Dwight had par values of less than $\$ 500$, with Dwight lowering its par value in 1871 prior to a recovery from several missed dividends and a period of rapid increase in the number of shareholders. The only firm whose ownership did not increase considerably after 1865 was the Lawrence Manufacturing Company. Significantly, it was one of only 14 listed industrial firms to maintain its initial par value of $\$ 1000$ throughout the sample period.

Several facets of liquidity that are reflected in the falling par values of industrials traded in Boston

${ }^{22}$ Trustees usually received multiple checks in their own name for trustors, but the names of the individual trustors also appeared on the dividend books.

${ }^{23}$ Estate distributions by large shareholders to multiple heirs account for part but certainly not all of the upward movement in Figure 8. For example, after counting the number of checks distributed by each firm to shareholders with unique last names, this "adjusted"ownership still rose by 27.5 percent for Dwight from 1864 to 1894, 22.1 percent for Lawrence between 1859 and 1884, 47.2 percent for Lyman between 1854 and 1894, 66.7 percent for Massachusetts Cotton between 1854 and 1894, and 150.7 percent for Pepperell between 1864 and 1894. It is thus unlikely that estate distributions accounted for more than half of the observed increases in the number of owners. 


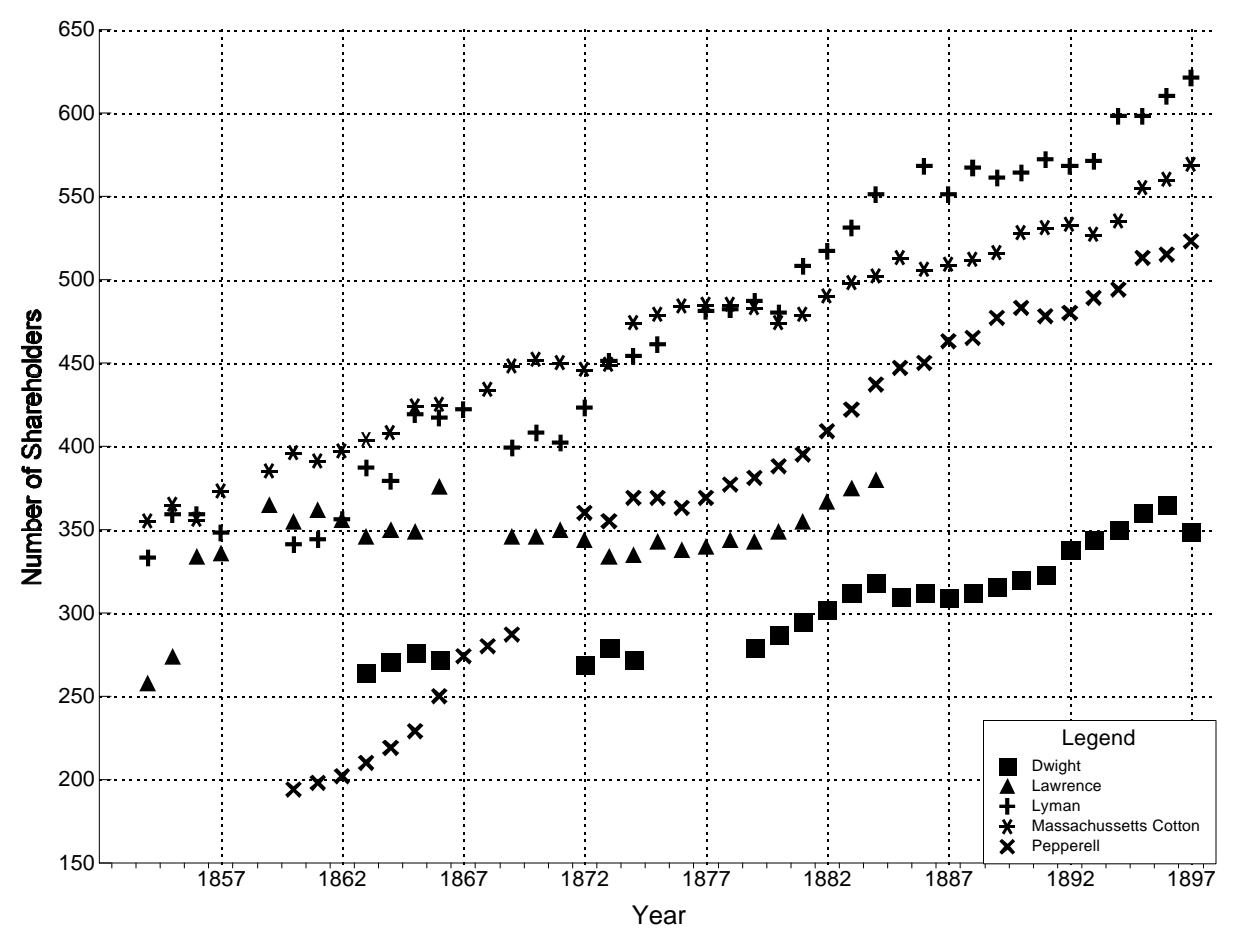

Figure 8. Number of Shareholders in Selected Industrial Firms

over a century ago are still relevant in today's emerging markets. In particular, widespread participation in equity markets remains central to their depth and stability, since the marketing of an individual's entire holdings in a firm with concentrated ownership may have startling price effects that lower market value significantly. To encourage participation and enjoy the price benefits of liquidity, owners today often choose to raise fresh capital publicly, implicitly accepting the possibility of initial underpricing and some dilution of control. In nineteenth-century Boston, the listing of a firm for public trading at what might be considered a reasonable par value also served to broaden ownership and reduce the price impact of large sales by individual investors, yet involved similar costs. Lower par values also made new securities easier for the Boston market to absorb, and the very existence of a viable exit mechanism for successful entrepreneurs appears to have encouraged its use. This exit mechanism also encouraged entry, and may have had effects on the industrial sector that reached well beyond those firms which actually used the 
market. The availability of entrepreneurial exit remains a key channel through which equity markets can affect the start of innovative projects. Of course, some dimensions of liquidity today differ considerably from those which operated in 1850 and may limit the degree to which parallels can be drawn across time. For example, lower par values do not reflect the enormous potential for excessive trading that low-cost electronic services now make possible.

\section{Measuring Regional Economic Performance}

Capturing a notion as broad as regional economic performance in the nineteenth century U.S. with a single summary measure presents both practical and conceptual limitations. In particular, annual estimates of per capita incomes, though available on a national basis in the unpublished worksheets of Simon Kuznets (1961) and Robert Gallman (1965), are generally unavailable for individual states and regions. In addition, the large segment of the population that continued to work outside of the formal labor market requires the use of earnings per gainfully-employed worker as a proxy for per capita income. Even summary measures of earnings are unavailable on an annual basis for all workers at the state or regional level. In New England, however, manufacturing workers dominated the formal labor force, accounting for about 40 percent of the gainfully-employed throughout the $1854-1897$ period. $^{24}$ This suggests that the earnings of industrial workers might be particularly useful for capturing long-run trends in per capita incomes for this region. Robert Layer (1955, Table 12, pp. 46-8) presents such a series on an annual basis for cotton mill operatives in New England between 1825 and 1914. It is constructed as the arithmetic mean of annual earnings in six large manufacturing firms, all of which were listed on the Boston Stock

\footnotetext{
${ }^{24}$ For example, Kuznets, Miller and Easterlin (1960, Table A.2.7, p. 85), using decennial census data, report that manufacturing industries in 1880 employed 41.5 percent of the labor force in Massachusetts, 47.4 percent in Rhode Island, 39.3 percent in Connecticut and 33 percent in New Hampshire. These percentages stood respectively at 37.1 percent, 44.3 percent, 35.9 percent and 35.4 percent in 1900.
} 


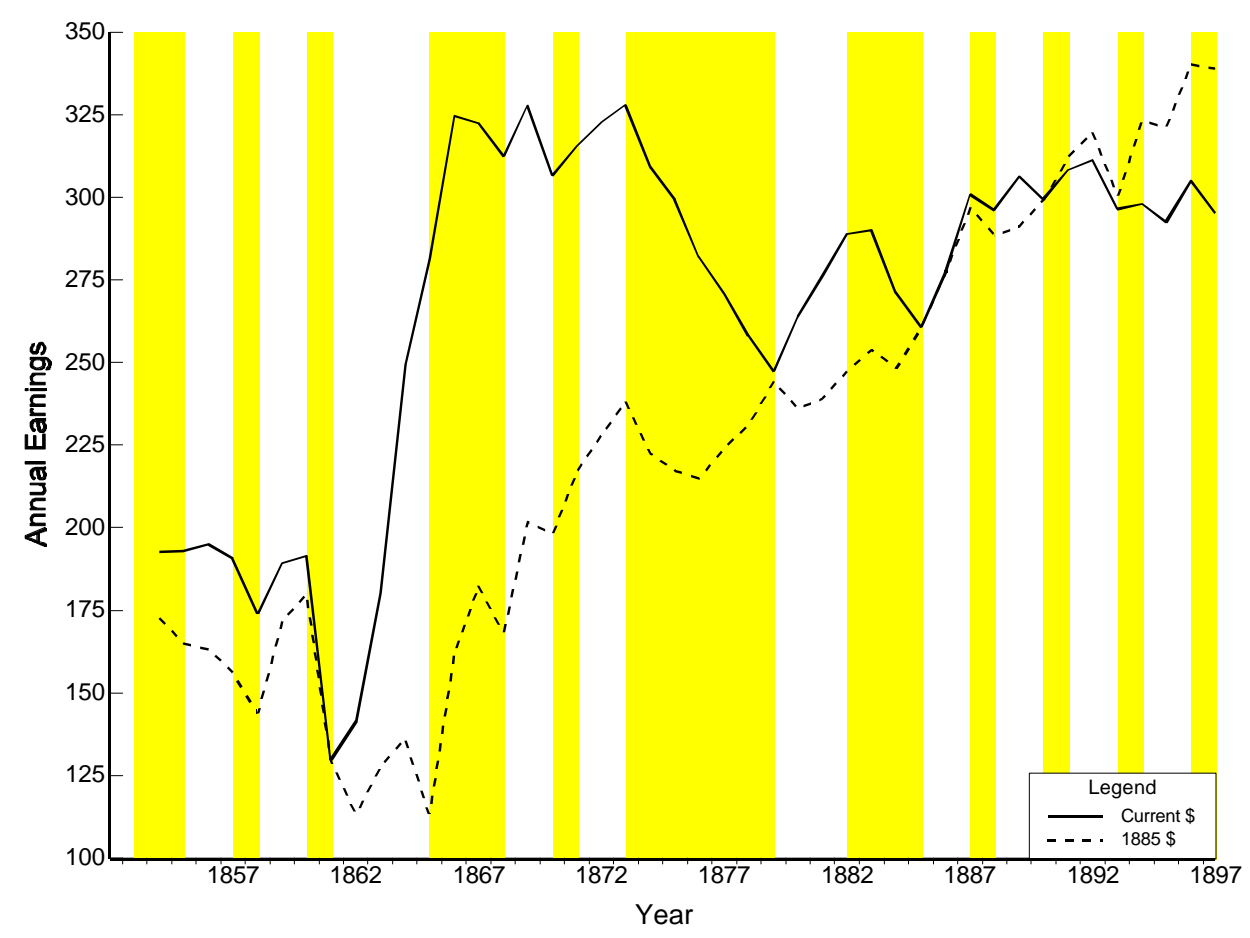

Figure 9. Average Annual Earnings of Industrial Mill Worker

Exchange. ${ }^{25}$ Despite its narrowness of scope, the series appears to represent reasonably well earnings in the region's cotton manufacturing industry, and perhaps even industrial earnings more generally. ${ }^{26}$ Less can be said about Layer's series as a proxy for per capita income, but it is perhaps reassuring that the

25 The Layer sample includes the Boston, Hamilton, Nashua, Lawrence, Dwight, and Lyman Manufacturing Companies. Because of its larger size, the Boston Manufacturing Company was assigned a weight of three in constructing the average prior to 1860. An average daily wage for each firm was first constructed as the quotient of the annual wage bill and the total number of days worked by all employees. Annual wages were then obtained as the product of the daily wage and the average number of days worked in each year by full-time employees of the mill.

${ }^{26}$ Layer's annual money earnings correspond closely to Long's (1960, table A-9, p. 150) independent decennial estimates of earnings in New England's cotton textile industry. For example, Layer reports annual earnings of \$192 in 1860, \$307 in 1870, \$264 in 1880, and \$299 in 1890; Long's estimates in these years are $\$ 205, \$ 303, \$ 253$, and $\$ 325$. Further, Layer's index of relative money earnings is strongly correlated (coefficient of 0.946) with Hansen's (1925) annual index for all industrial workers in the U.S. A comparison of the Layer and Hansen series also suggests that the weakening of the position of New England mill operatives with respect to other industrial workers had ended by 1860 and that the gap remained relatively steady thereafter (Layer 1955, p. 50). 
unweighted averages of Richard Easterlin's estimates of personal income per capita in Massachusetts, Rhode Island, Connecticut and New Hampshire in 1880 and 1900 (Kuznets, Miller, and Easterlin 1960, p. 188) fall within $\$ 7$ of Layer's estimates. Figure 9 presents Layer's series. With the exception of the downturn of 1857 and the inflationary Civil War years, real earnings advanced fairly steadily through 1897. ${ }^{27}$ Howard (1920, table XIX, p. 150) presents an alternate series for annual money earnings in the Massachusetts textile industry from 1860 to 1897 , which I use in the empirical analysis to verify the robustness of results obtained with Layer's data. ${ }^{28}$

The marginal productivity theory of wages suggests that increases in the average product of labor in a competitive market which are brought about by increases in capital intensity should result in a less than proportionate and delayed rise in wages. In the case of increased efficiency, labor also remains unable to retain all of the accompanying increases in output. Nevertheless, movements in wages and annual earnings of industrial workers should broadly reflect productivity in the sector. As equity markets might be expected to facilitate the application of additional capital to production processes and increase the efficiency of labor by directing funds to the most promising projects, one might also expect earnings to be related to the level of capital market sophistication. This appears to have been the case for New England's textile industry (McGouldrick, 1968, pp. 144-148), especially since the shift in labor force composition from rural young women to immigrants who were perhaps less averse to higher work intensity was also largely complete by the mid-1850s. ${ }^{29}$

${ }^{27}$ Overall, nominal wages rose by 111 percent between 1854 and 1897 . The real wages, which use Hansen's (1925) cost-of-living index for deflation, rose by 99 percent.

${ }^{28}$ Howard's series uses estimates from Mitchell (1908) for 1860-1880, the 1893 Aldrich Report of the U.S. Senate Finance Committee for 1881-1890, and the U.S. Bureau of Labor thereafter.

${ }^{29}$ Layer (1955, Appendix C, pp. 70-71) reports that 52.5 percent of operatives at the Hamilton Manufacturing Company in 1855 were foreign-born. This share rises to 58.2 in 1859, falls to 49 percent prior to the resumption of full operations in 1866, and reaches 56.5 percent by 1872 . Census data which are less precise but perhaps more representative (Copeland 1917, p. 118) indicate that 36 percent of all 


\section{Finance as a Leading Sector}

\section{A. Model Selection and Empirical Methodology}

It is noted in Section I that periods of rapid advance in the prices (Figure 1 and 2) and real capitalizations (Figure 6) of both traded banks and industrial firms coincided with those of falling industrial par values (Figure 7). These observations suggest that liquidity in the equity market may have been importantly related to both the size and performance of New England's industrial sector in the second half of the nineteenth century. In this section, I describe a set of vector autoregressive (VAR) models and a testing strategy that can be used with the newly-constructed data series to evaluate more formally the direction, size and timing of these possible relationships.

The appropriateness of the number of shares per $\$ 1000$ of equity capital (LIQUID hereafter) as a measure of market liquidity is central to the analysis. Since recent macroeconomic models by Bencivenga, Smith, and Starr (1995) and Greenwood and Smith (1997) have related liquidity directly to the size of the market, one might expect a reasonable measure of liquidity to play a leading role in the increasing capitalization of industrial firms. As banks and industrials traded at the same public auctions and together accounted for the vast majority of securities traded via this mechanism, the LIQUID measure may also reflect liquidity in the market for banks, which for the most part maintained steady par values of $\$ 100$ throughout the sample period. The empirical analysis thus begins by examining dynamic relationships in a tri-variate system that includes LIQUID and the real market capitalizations of industrials (ICAP) and banks (BCAP).

The plots in Section I also suggest that increases in liquidity may be related to permanent movements in the level of stock prices. A second tri-variate VAR that includes LIQUID and the market

cotton mill operatives were foreign-born by 1870, and that this percentage rises to 47 percent by 1890 . 
value-weighted indices of industrial prices (IPRICE) and total bank returns (BRET) is estimated to evaluate this effect. Bank equity returns are a key control variable since industrial firms relied heavily on banks for short-term finance from at least the mid-1850s (Davis, 1960; McGouldrick, 1968, pp.16-17). Further, Atack and Rousseau (1999) have found that lower bank returns in the Boston market prior to 1870 tended to contribute to monetary stringency which raised the cost of working capital and inhibited its use. This central role for banks in business activity suggests that banking conditions may be linked to the performance, both expected and actual, of industrial firms.

Three additional specifications verify the link from market size and liquidity to economic performance. In these systems, Layer's (1955) estimates of annual earnings for full-time mill operatives in New England serve as a proxy for per capita income and the return to industrial labor, which should rise with the expansion of banking resources and the liquidity of the equity market. Specifically, these systems consider the plausibility of LIQUID, ICAP and BCAP as leading factors in explaining fluctuations in nominal wages using the level of industrial prices (IPRICE) to control for overall conditions in the manufacturing sector, including variations in the general level of prices.

The VAR methodology permits an investigation of dynamic interactions in a stationary multivariate system that does not impose a priori structural restrictions. It involves estimating a separate regression equation for each variable on its own lags and those of the other variables in the system. For example, the first VAR described above has the form

$$
\begin{aligned}
& x_{1, t}=a_{1,0}+\sum_{i=1}^{k} a_{1, i} x_{1, t-i}+\sum_{i=1}^{k} b_{1, i} x_{2, t-i}+\sum_{i=1}^{k} c_{1, i} x_{3, t-i}+u_{1, t} \\
& x_{2, t}=a_{2,0}+\sum_{i=1}^{k} a_{2, i} x_{1, t-i}+\sum_{i=1}^{k} b_{2, i} x_{2, t-i}+\sum_{i=1}^{k} c_{2, i} x_{3, t-i}+u_{2, t} \\
& x_{3, t}=a_{3,0}+\sum_{i=1}^{k} a_{3, i} x_{1, t-i}+\sum_{i=1}^{k} b_{3, i} x_{2, t-i}+\sum_{i=1}^{k} c_{3, i} x_{3, t-i}+u_{3, t}
\end{aligned}
$$

where $x_{1}$ and $x_{2}$ are the respective real market capitalizations of the industrial (ICAP) and banking (BCAP) 
sectors, $x_{3}$ is LIQUID, and $k$ is the number of lags.

Stationarity of a VAR is critical in interpreting tests for Granger non-causality, that is the hypothesis that past values of one variable do not jointly improve one-step ahead forecasts of another. Specifically, the null hypothesis implies the following joint restrictions on the coefficients in (1):

$$
\hat{l}_{j, i}=\hat{l}_{j, i+1}=\ldots=\hat{l}_{j, k}=0 \quad l=a, b, c ; j=1,2,3 .
$$

In general, the distributions of these tests are affected by nuisance parameters (see Toda and Phillips, 1993) and are thus nonstandard when a VAR contains variables with unit roots, and differencing is usually required to ensure stationarity. Sims, Stock, and Watson (1990) show, however, that Granger tests for non-causality conform to standard distributions in tri-variate VARs with unit roots so long as a single cointegrating relationship exists among the system variables. In this case, tests for block exclusion can be computed from the levels specification which allow both short- and long-term factors to contribute to the measurable effects of a particular variable on others.

The Sims, Stock, and Watson result is particularly important in the five tri-variate VARs specified here because the null hypothesis of a unit root cannot be rejected with standard tests for any of the variables ${ }^{30}$ and there appears to be single cointegrating relationship in each system. ${ }^{31}$ It implies that VAR

${ }^{30}$ Augmented Dickey-Fuller (Said and Dickey, 1984) and Phillips-Perron (1988) tests for unit roots were computed for all series used in the empirical analysis. Both tests clearly suggest non-stationarity in levels and stationarity in first differences for all but one case. The tests conflict only for bank stock returns, where ADF tests with two to five lags do not reject the unit root hypothesis while the PhillipsPerron test rejects the null. Since the price appreciation component of returns appears to be stationary and the dividend yield component appears to be non-stationary, the analysis proceeds by allowing bank stock returns to enter its tri-variate system in levels. Table A2 in the Appendix presents the full set of results and describes details of the test regressions.

${ }^{31}$ Inferences about the cointegration space in each system are based on the technique developed by Johansen (1991), which identifies the number of cointegrating relationships in a VAR system with nonstationary variables and delivers maximum likelihood estimates of the cointegrating vector, that is a set of loadings that yields a stationary result when applied to the variables in a cointegrated system. Table A3 of the Appendix presents the complete results of the Johansen tests for the VAR systems described above. 
specifications in levels are appropriate for drawing Granger-causal inferences.

Granger-causality tests must be interpreted with due caution, since as a statistical device the notion of Granger-causality does not necessarily imply "economic causality." In particular, the validity of the tests is predicated on the inclusion of the full information set in the VAR specifications. Since this condition is necessarily violated in any finite regression framework, the results presented in the following subsections can only be interpreted as strongly suggestive of the nature of timing relationships among the variables in each system.

When an investigator can specify a reasonable causal ordering for the variables in a VAR system (based on economic theory and perhaps the results of Granger tests), the nonlinear and often complex responses of each variable in the system to one-time shocks in the other variables can be traced through time via orthogonalized impulse responses. Such an analysis also allows an evaluation of the economic significance (or size) of these dynamic effects. For this reason, the results of Granger tests are augmented with a graphical examination of the more interesting impulse responses for each system.

\section{B. The Effects of Liquidity on Market Size}

The empirical investigation begins with estimation of the system that includes the logs of LIQUID, BCAP and ICAP. Nested likelihood ratio tests select a specification with two lags. ${ }^{32}$ Table 1 reports the regression coefficients, with the significance level of the F-test for Granger causality for each block of coefficients in parentheses. LIQUID Granger-causes ICAP at the 7 percent level and BCAP at the 14 percent level. There is no evidence of feedback from the capitalization of either sector to LIQUID, which suggests that the effects of market liquidity are unidirectional. BCAP also Granger-causes ICAP at the 9 percent level.

\footnotetext{
${ }^{32}$ This method starts with a sufficiently large lag length and then tests successively that the coefficients on the final lag are zero, stopping when the restrictions are rejected.
} 
Table 1

The Effects of Liquidity on Equity Market Depth, 1854-1897 ${ }^{\mathrm{a}}$

\begin{tabular}{|c|c|c|c|c|c|c|c|}
\hline Dependent Variable & $\mathrm{ICAP}_{-1}$ & $\mathrm{ICAP}_{-2}$ & $\mathrm{BCAP}_{-1}$ & $\mathrm{BCAP}_{-2}$ & LIQUID $_{-1}$ & LIQUID $_{-2}$ & $\mathrm{R}^{2}$ \\
\hline $\begin{array}{l}\text { Market Capitalization of } \\
\text { Industrials (ICAP) }\end{array}$ & $\begin{array}{c}0.922 \\
(0.168)\end{array}$ & $\begin{array}{c}0.054 \\
(0.165)\end{array}$ & $\begin{array}{l}-0.010 \\
(0.126)\end{array}$ & $\begin{array}{c}0.142 \\
(0.120)\end{array}$ & $\begin{array}{c}0.070 \\
(0.082)\end{array}$ & $\begin{array}{l}-0.178 \\
(0.080)\end{array}$ & 0.995 \\
\hline F-test (p-value) & \multicolumn{2}{|c|}{$324.81(.000)$} & \multicolumn{2}{|c|}{$2.625(.087)$} & \multicolumn{2}{|c|}{$2.822(.073)$} & \\
\hline $\begin{array}{l}\text { Market Capitalization of } \\
\text { Banks (BCAP) }\end{array}$ & $\begin{array}{l}-0.346 \\
(0.222)\end{array}$ & $\begin{array}{c}0.308 \\
(0.219)\end{array}$ & $\begin{array}{l}1.095 \\
(0.167)\end{array}$ & $\begin{array}{l}-0.216 \\
(0.159)\end{array}$ & $\begin{array}{c}0.219 \\
(0.109)\end{array}$ & $\begin{array}{l}-0.113 \\
(0.105)\end{array}$ & 0.986 \\
\hline F-test (p-value) & \multicolumn{2}{|c|}{$1.337(.275)$} & \multicolumn{2}{|c|}{$61.60(.000)$} & \multicolumn{2}{|c|}{$2.089(.139)$} & \\
\hline $\begin{array}{l}\text { Shares Per } \$ 1000 \text { of Book } \\
\text { Capital (LIQUID) }\end{array}$ & $\begin{array}{l}-0.462 \\
(0.352)\end{array}$ & $\begin{array}{c}0.549 \\
(0.347)\end{array}$ & $\begin{array}{c}0.087 \\
(0.265)\end{array}$ & $\begin{array}{c}0.116 \\
(0.252)\end{array}$ & $\begin{array}{c}0.824 \\
(0.172)\end{array}$ & $\begin{array}{l}-0.147 \\
(0.167)\end{array}$ & 0.974 \\
\hline$F$-test (p-value) & \multicolumn{2}{|c|}{$1.750(.189)$} & \multicolumn{2}{|c|}{$1.231(.304)$} & \multicolumn{2}{|c|}{$15.903(.000)$} & \\
\hline
\end{tabular}

${ }^{a}$ All variables are in log levels. The columns report the regression coefficients with standard errors in parentheses. F statistics for the null hypothesis of Granger non-causality appear beneath each block of coefficients with significance levels in parentheses.

Since regression coefficients can be sometimes misleading about the general direction of dynamic linkages in systems characterized by complex interactions, it is often more informative to examine the impulse responses. These responses, shown in Figure 10 for selected cases, orthogonalize the error terms by ordering LIQUID first, BCAP second, and ICAP last. The ordering is consistent with increasing endogeneity as implied by the Granger causality tests.

These plots suggest positive overall effects of LIQUID on both BCAP and ICAP, and the sizes of the effects are considerable. For example, the upper left panel of Figure 10 implies that an increase of 10 percent in LIQUID from its sample mean of 4.55 , which corresponds to a $\$ 20$ decrease in the par value of a typical share from its sample mean of $\$ 220$, is related to a rise of about 4 percent in real bank capitalization after three years from its sample mean of $\$ 55.65$ million (or about $\$ 2.23$ million). The same shock implies a rise in real industrial capital (upper right panel of Figure 10) of 1.85 percent after one year 

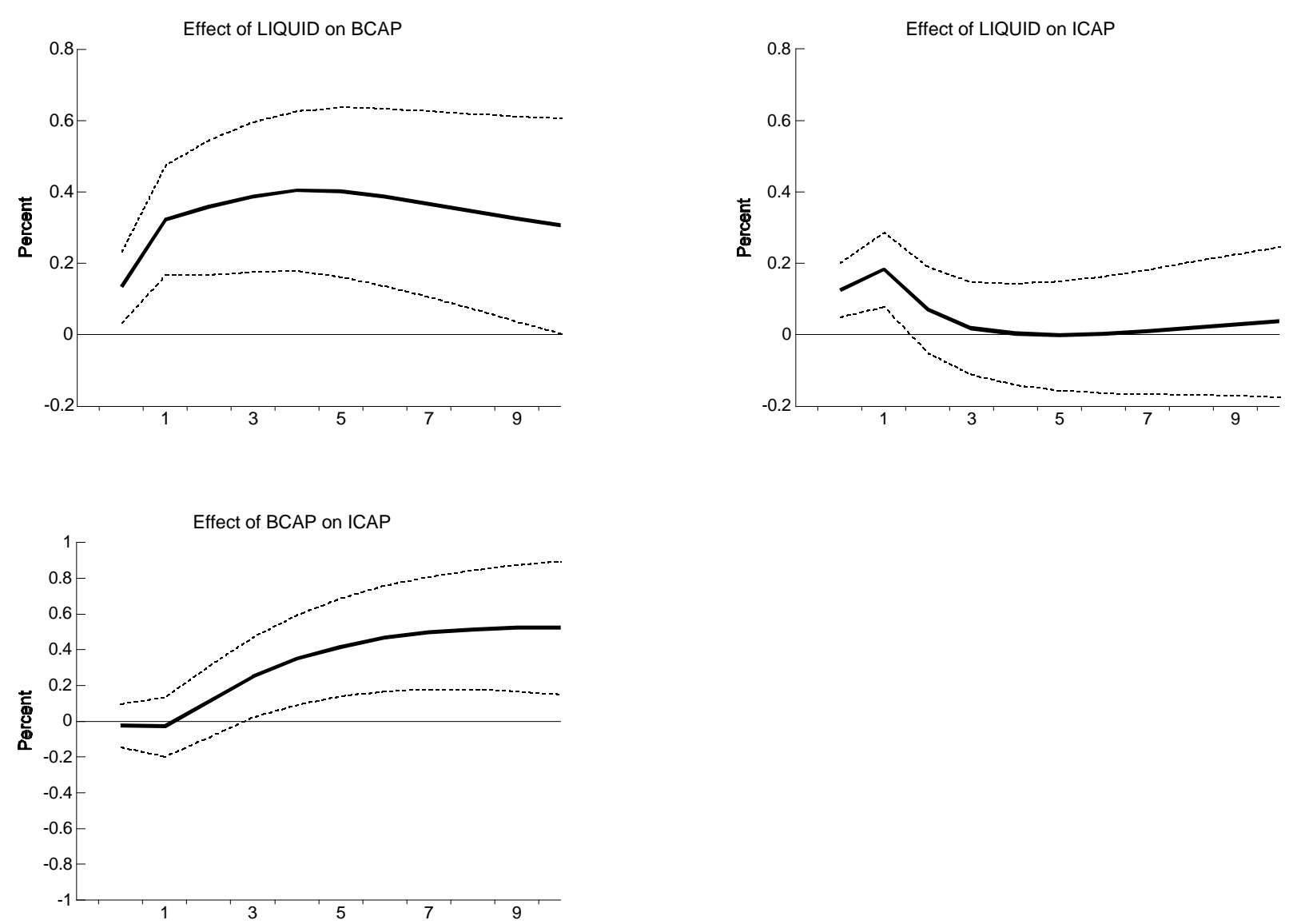

Figure 10. Selected impulse responses from system with LIQUID, BCAP, and ICAP

Notes: The impulse responses correspond to the system reported in Table 1. Each plot traces the percent change in the affected variable that results over a ten-year horizon from a 1 percent change in the orthogonalized innovation to the potentially causal variable. The variable ordering places LIQUID first, BCAP second, and ICAP third. Using the Monte Carlo integration technique outlined in Doan (1995), the thick solid lines plot the mean impulse responses that result from 10,000 random draws from the posterior distribution of the estimated VAR coefficients. The dotted lines are one standard error bands.

from its sample mean of $\$ 55.46$ million (or about $\$ 1.03$ million).

The prominent response of bank capitalization to increases in the liquidity measure reflects the growth and increasing sophistication of auctions conducted outside of the exchange in which trades of both banking and industrial equities strongly dominated. Since participation constraints were less binding for bank stocks than for industrials due to par values that were traditionally lower, the liquidity engendered 
by more active industrial trading in their shared transaction mechanism had even larger effects on the capitalization of banks than industrials. The lower left panel of Figure 10 relates a 10 percent increase in BCAP to a 5 percent rise in ICAP, which is consistent with the Granger-causality test and suggests a strong complementary role for banks in promoting an expansion of industrial capital. ${ }^{33}$ The smaller yet clearly positive response of industrial capitalization to increases in the liquidity measure reflects par values which, even after the reductions depicted in Figure 7, continued to pose some participation constraints to potential investors. In addition, the lag structure of the VAR cannot in the absence of stronger identification assumptions capture the effects of restructuring packages in which par values were commonly reduced and authorized capital increased in anticipation of the greater liquidity and demand for fresh equity shares that lower prices would bring.

The results suggest that share liquidity promoted the rising capitalizations of banks and industrials, yet do not offer insights about its potential effects on industrial performance and regional economic growth that extend beyond expansion of the sector. In particular, a liquid market should yield higher firm valuations than an illiquid market and should promote more efficient allocations of financial resources. The remaining subsections examine these less direct yet important channels through which liquidity may have affected industrial growth and general economic conditions in New England.

\section{Liquidity and the Centrality of Banking}

The next system considers the log of the industrial price index (IPRICE), annual bank returns (BRET), and the log of LIQUID. In this case, nested likelihood ratio tests select a specification with three lags. Table 2 presents the results. LIQUID Granger-causes IPRICE at the 10 percent level, while BRET Granger-causes IPRICE at less than the 1 percent level. There is no evidence of feedback from industrial

\footnotetext{
${ }^{33}$ The remaining impulse responses from the system are consistent with the Granger tests, which do not indicate other significant leading relationships among the system variables.
} 
Table 2

Market Liquidity, Bank Returns and Industrial Performance, $1854-1897^{\mathrm{a}}$

\begin{tabular}{|c|c|c|c|c|c|c|c|c|c|c|}
\hline Dependent Variable & IPRICE $_{-1}$ & IPRICE $_{-2}$ & IPRICE $_{-3}$ & BRET $_{-1}$ & $\mathrm{BRET}_{-2}$ & BRET $_{-3}$ & LIQUID $_{-1}$ & LIQUID $_{-2}$ & LIQUID $_{-3}$ & $\mathrm{R}^{2}$ \\
\hline $\begin{array}{l}\text { Industrial Prices } \\
\text { (IPRICE) }\end{array}$ & $\begin{array}{c}0.736 \\
(0.202)\end{array}$ & $\begin{array}{l}-0.300 \\
(0.256)\end{array}$ & $\begin{array}{l}-0.107 \\
(0.172)\end{array}$ & $\begin{array}{c}1.253 \\
(0.261)\end{array}$ & $\begin{array}{l}-0.182 \\
(0.343)\end{array}$ & $\begin{array}{c}0.107 \\
(0.320)\end{array}$ & $\begin{array}{c}0.014 \\
(0.499)\end{array}$ & $\begin{array}{c}0.274 \\
(0.617)\end{array}$ & $\begin{array}{c}0.519 \\
(0.430)\end{array}$ & 0.795 \\
\hline$F$-test (p-value) & \multicolumn{3}{|c|}{$5.580(.004)$} & \multicolumn{3}{|c|}{$7.823(.001)$} & \multicolumn{3}{|c|}{$2.259(.101)$} & \\
\hline $\begin{array}{l}\text { Bank Returns } \\
\text { (BRET) }\end{array}$ & $\begin{array}{c}0.212 \\
(0.142)\end{array}$ & $\begin{array}{l}-0.039 \\
(0.180)\end{array}$ & $\begin{array}{l}-0.062 \\
(0.121)\end{array}$ & $\begin{array}{l}-0.072 \\
(0.183)\end{array}$ & $\begin{array}{l}-0.140 \\
(0.242)\end{array}$ & $\begin{array}{l}-0.225 \\
(0.225)\end{array}$ & $\begin{array}{l}-0.308 \\
(0.351)\end{array}$ & $\begin{array}{c}0.277 \\
(0.434)\end{array}$ & $\begin{array}{c}0.087 \\
(0.303)\end{array}$ & 0.311 \\
\hline$F$-test (p-value) & \multicolumn{3}{|c|}{$1.114(.358)$} & \multicolumn{3}{|c|}{$0.536(.661)$} & \multicolumn{3}{|c|}{$0.354(.786)$} & \\
\hline $\begin{array}{l}\text { Shares Per } \$ 1000 \text { of Book } \\
\text { Capital (LIQUID) }\end{array}$ & $\begin{array}{c}0.059 \\
(0.077)\end{array}$ & $\begin{array}{l}-0.110 \\
(0.097)\end{array}$ & $\begin{array}{c}0.033 \\
(0.065)\end{array}$ & $\begin{array}{c}0.184 \\
(0.099)\end{array}$ & $\begin{array}{l}-0.161 \\
(0.131)\end{array}$ & $\begin{array}{l}-0.033 \\
(0.122)\end{array}$ & $\begin{array}{c}0.847 \\
(0.190)\end{array}$ & $\begin{array}{l}-0.164 \\
(0.235)\end{array}$ & $\begin{array}{c}0.244 \\
(0.164)\end{array}$ & 0.976 \\
\hline$F$-test (p-value) & \multicolumn{3}{|c|}{$0.477(.701)$} & \multicolumn{3}{|c|}{$1.687(.191)$} & \multicolumn{3}{|c|}{$19.838(.000)$} & \\
\hline
\end{tabular}

\footnotetext{
${ }^{\mathrm{a}}$ The system includes a constant and time trend. IPRICE and LIQUID are in log levels. The columns report the regression coefficients with standard errors in parentheses. F statistics for the null hypothesis of Granger non-causality appear beneath each block of coefficients with significance levels in parentheses.
} 

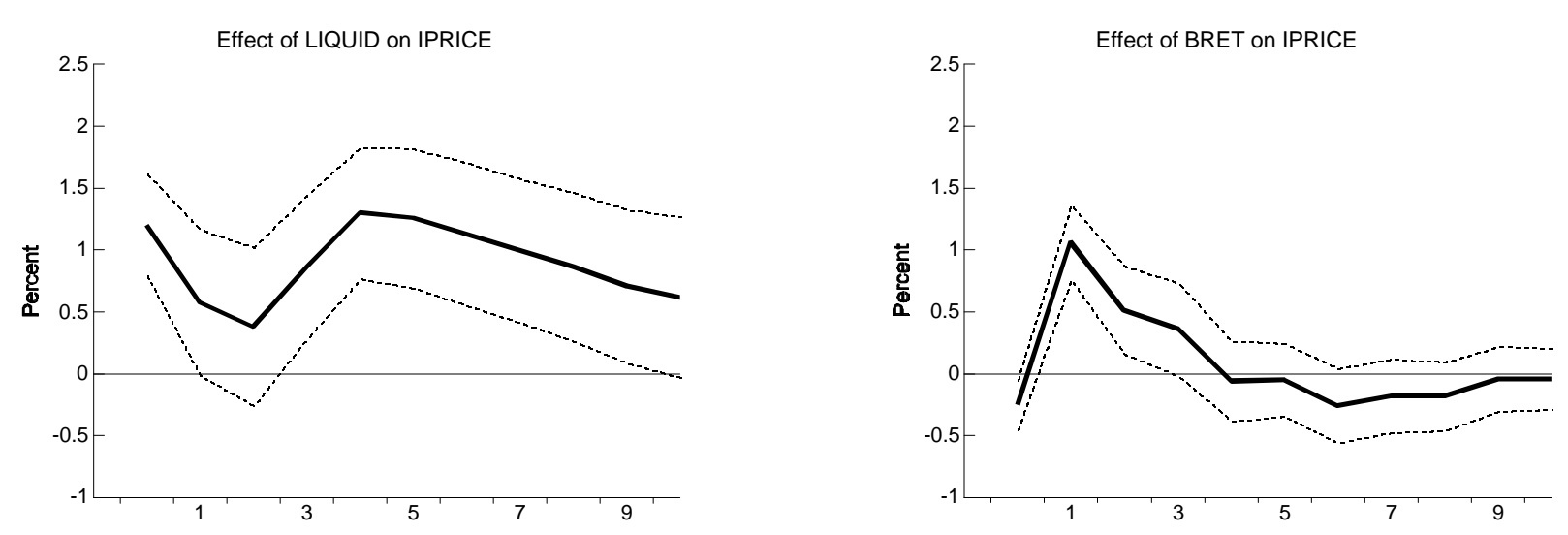

Figure 11. Selected impulse responses from system with LIQUID, BRET, and IPRICE

Notes: The impulse responses correspond to the system in Table 2, with LIQUID placed first in the variable ordering, BRET second, and IPRICE third. See note to Figure 10 for further details.

prices to bank returns or market liquidity.

The impulse responses (Figure 11), which order LIQUID first, BRET second and IPRICE third, suggest that the effects indicated in Table 2 are indeed large. For example, a one percent increase in LIQUID (or a \$2 decrease in the average par value of industrial shares from their sample mean of \$220) is associated with a 1.3 percent increase in the level of industrial prices after four years. This suggests that the deepening and increasingly liquid equity market had considerable long-term price effects. To the extent that industrial prices reflect actual and anticipated economic performance in the sector, liquidity also appears to have improved the efficiency with which resources were delivered to productive uses. Fundamentals in the banking sector, as reflected by the total returns of shareholders, also influenced the short-term behavior of industrial prices, with an impulse response that rises rapidly and then gradually decays. Quantitatively, a single percentage point increase in bank returns is associated with a rise of slightly more than one percent in the level of industrial prices. Since the average par value of industrial firms in the sample over the full 1854-1897 period was about $\$ 520$ and share prices generally fluctuated around their par values, such a shock can be associated with an increase of more than $\$ 5$ in the price of a 
typical share. These findings are consistent with the view that industrial firms relied extensively on banks for short-term financing.

\section{Market Development and Annual Earnings of Industrial Workers}

Table 3 presents results from the three VARs which in turn relate liquidity and the real market capitalizations of traded industrials (ICAP) and banks (BCAP) to the annual earnings of industrial mill operatives. ${ }^{34}$ Since these systems, for which nested likelihood ratio tests also select three lags, seek to identify independent effects of financial markets on the incomes of industrial workers and the returns to their labor, the level of industrial prices (IPRICE) is included as a parsimonious control for other factors which influence industrial conditions. These factors include inflation, input prices, and fluctuations in product demand, some of which may be the result of a rapid expansion of Southern textile mills after 1880.

LIQUID serves as the measure of market development in the first system (upper panel of Table 3) and Granger-causes both earnings and industrial prices at the 1 percent level with positive overall effects. As might be expected, weaker evidence also suggests that higher earnings had a negative effect on stock prices. The second system, which uses ICAP as the measure of market development, yields broadly similar results-ICAP and IPRICE Granger-cause earnings at the 5 and 1 percent levels respectively. In the final system (lower panel of Table 3), BCAP Granger-causes earnings at the 10 percent level. In all three systems, there is weak evidence (at the 15 percent level) of feedback from earnings to the liquidity measure, but the overall effects as approximated by the sum of the regression coefficients are very small.

The responses of earnings to shocks in the measures of market development (Figure 12) are again

34 Note to Table 3: Each VAR includes the annual earnings of industrial workers in New England (EARN), the level of industrial equity prices (IPRICE), and the measure of market development listed at the left. All quantities are in log levels. The columns report the regression coefficients with standard errors in parentheses. F statistics for the null hypothesis of Granger non-causality appear beneath each block of coefficients with significance levels in parentheses. 
Dependent Variable

Annual Earnings of Industrial Worker (EARN)

F-test (p-value)

Index of Industrial Prices (IPRICE)

F-test (p-value)

Shares Per $\$ 1000$ of Book Capital (LIQUID)

F-test (p-value)

Annual Earnings of Industrial Worker (EARN)

F-test (p-value)

Index of Industrial Prices (IPRICE)

F-test (p-value)

Real Market Capitalization of Industrials (ICAP)

F-test (p-value)

Annual Earnings of Industrial Worker (EARN)

$F$-test (p-value)

Index of Industrial Prices (IPRICE)

F-test (p-value)

Real Market Capitalization of Banks (BCAP)

F-test (p-value) $\begin{array}{lllllllllll}\text { EARN }_{-1} & \mathrm{EARN}_{-2} & \mathrm{EARN}_{-3} & \text { IPRICE }_{-1} & \text { IPRICE }_{-2} & \text { IPRICE }_{-3} & \mathrm{MktDev}_{-1} & \mathrm{MktDev}_{-2} & \mathrm{MktDev}_{-3} & \mathrm{R}^{2}\end{array}$

$\begin{array}{llllllllll}0.916 & -0.382 & -0.103 & 0.161 & -0.124 & 0.336 & -0.762 & 0.669 & 0.405 & 0.909\end{array}$

$\begin{array}{lllllllll}(0.165) & (0.221) & (0.162) & (0.146) & (0.161) & (0.136) & (0.447) & (0.582) & (0.397)\end{array}$

\begin{tabular}{ccccccccccc}
\multicolumn{3}{c}{$13.395(.000)$} & \multicolumn{3}{c}{$4.104(.015)$} & \multicolumn{3}{c}{$5.342(.004)$} \\
0.258 & -0.707 & 0.251 & 0.674 & 0.265 & -0.103 & -0.430 & 0.179 & 0.337 & 0.650 \\
$(0.232)$ & $(0.311)$ & $(0.228)$ & $(0.206)$ & $(0.226)$ & $(0.192)$ & $(0.629)$ & $(0.819)$ & $(0.559)$ \\
\multicolumn{3}{c}{$2.532(.075)$} & \multicolumn{3}{c}{$10.698(.000)$} & \multicolumn{3}{c}{$0.468(.707)$} \\
0.040 & -0.221 & 0.156 & 0.014 & 0.001 & -0.005 & 0.825 & -0.081 & 0.203 & 0.978 \\
$(0.064)$ & $(0.086)$ & $(0.063)$ & $(0.057)$ & $(0.063)$ & $(0.053)$ & $(0.174)$ & $(0.227)$ & $(0.155)$ &
\end{tabular}

$1.958(.141)$

$0.032(.992)$

$179.25(.000)$

\begin{tabular}{ccccccccccc}
0.962 & -0.452 & 0.006 & 0.070 & -0.004 & 0.412 & 1.180 & -0.797 & -0.128 & 0.892 \\
$(0.176)$ & $(0.235)$ & $(0.165)$ & $(0.151)$ & $(0.168)$ & $(0.146)$ & $(0.934)$ & $(1.332)$ & $(0.914)$ & \\
$12.500(.000)$ & \multicolumn{7}{c}{$4.785(.007)$} & \multicolumn{3}{c}{$2.922(.049)$} \\
0.315 & -0.755 & 0.319 & 0.639 & 0.296 & -0.105 & -0.305 & -0.086 & 0.399 & 0.636 \\
$(0.232)$ & $(0.310)$ & $(0.218)$ & $(0.199)$ & $(0.221)$ & $(0.192)$ & $(1.232)$ & $(1.756)$ & $(1.205)$ \\
\multicolumn{7}{c}{$9.803(.000)$} & \multicolumn{7}{c}{$0.064(.978)$} \\
0.033 & -0.122 & 0.098 & 0.019 & -0.002 & -0.025 & 1.017 & -0.030 & -0.012 & 0.996 \\
$(0.030)$ & $(0.040)$ & $(0.028)$ & $(0.026)$ & $(0.028)$ & $(0.025)$ & $(0.158)$ & $(0.226)$ & $(0.155)$ &
\end{tabular}

\begin{tabular}{|c|c|c|c|c|c|c|c|c|c|}
\hline \multicolumn{3}{|c|}{$2.172(.111)$} & \multicolumn{3}{|c|}{$0.488(.693)$} & \multicolumn{3}{|c|}{$1329.4(.000)$} & \multirow[b]{2}{*}{0.887} \\
\hline $\begin{array}{c}0.930 \\
(0.192)\end{array}$ & $\begin{array}{l}-0.300 \\
(0.252)\end{array}$ & $\begin{array}{l}-0.097 \\
(0.198)\end{array}$ & $\begin{array}{r}0.083 \\
(0.154)\end{array}$ & $\begin{array}{c}-0.014 \\
(0.168)\end{array}$ & $\begin{array}{c}0.318 \\
(0.173)\end{array}$ & $\begin{array}{l}-0.587 \\
(0.933)\end{array}$ & $\begin{array}{c}0.841 \\
(1.252)\end{array}$ & $\begin{array}{c}0.019 \\
(0.775)\end{array}$ & \\
\hline \multicolumn{3}{|c|}{$12.096(.000)$} & \multicolumn{3}{|c|}{$2.764(.059)$} & \multicolumn{3}{|c|}{$2.390(.088)$} & \\
\hline $\begin{array}{c}0.334 \\
(0.243)\end{array}$ & $\begin{array}{l}-0.666 \\
(0.319)\end{array}$ & $\begin{array}{c}0.204 \\
(0.251)\end{array}$ & $\begin{array}{c}0.627 \\
(0.195)\end{array}$ & $\begin{array}{c}0.282 \\
(0.213)\end{array}$ & $\begin{array}{l}-0.127 \\
(0.219)\end{array}$ & $\begin{array}{c}-0.527 \\
(1.182)\end{array}$ & $\begin{array}{c}1.547 \\
(1.586)\end{array}$ & $\begin{array}{l}-0.918 \\
(0.982)\end{array}$ & 0.650 \\
\hline \multicolumn{3}{|c|}{$1.559(.219)$} & \multicolumn{3}{|c|}{$8.216(.000)$} & \multicolumn{3}{|c|}{$0.474(.703)$} & \\
\hline $\begin{array}{c}0.047 \\
(0.040)\end{array}$ & $\begin{array}{c}0.011 \\
(0.052)\end{array}$ & $\begin{array}{c}0.008 \\
(0.041)\end{array}$ & $\begin{array}{c}0.060 \\
(0.032)\end{array}$ & $\begin{array}{c}-0.101 \\
(0.035)\end{array}$ & $\begin{array}{c}0.030 \\
(0.036)\end{array}$ & $\begin{array}{c}1.193 \\
(0.194)\end{array}$ & $\begin{array}{c}-0.418 \\
(0.260)\end{array}$ & $\begin{array}{c}0.112 \\
(0.161)\end{array}$ & 0.989 \\
\hline \multicolumn{3}{|c|}{$2.141(.115)$} & \multicolumn{3}{|c|}{$3.033(.044)$} & \multicolumn{3}{|c|}{$259.91(.000)$} & \\
\hline
\end{tabular}



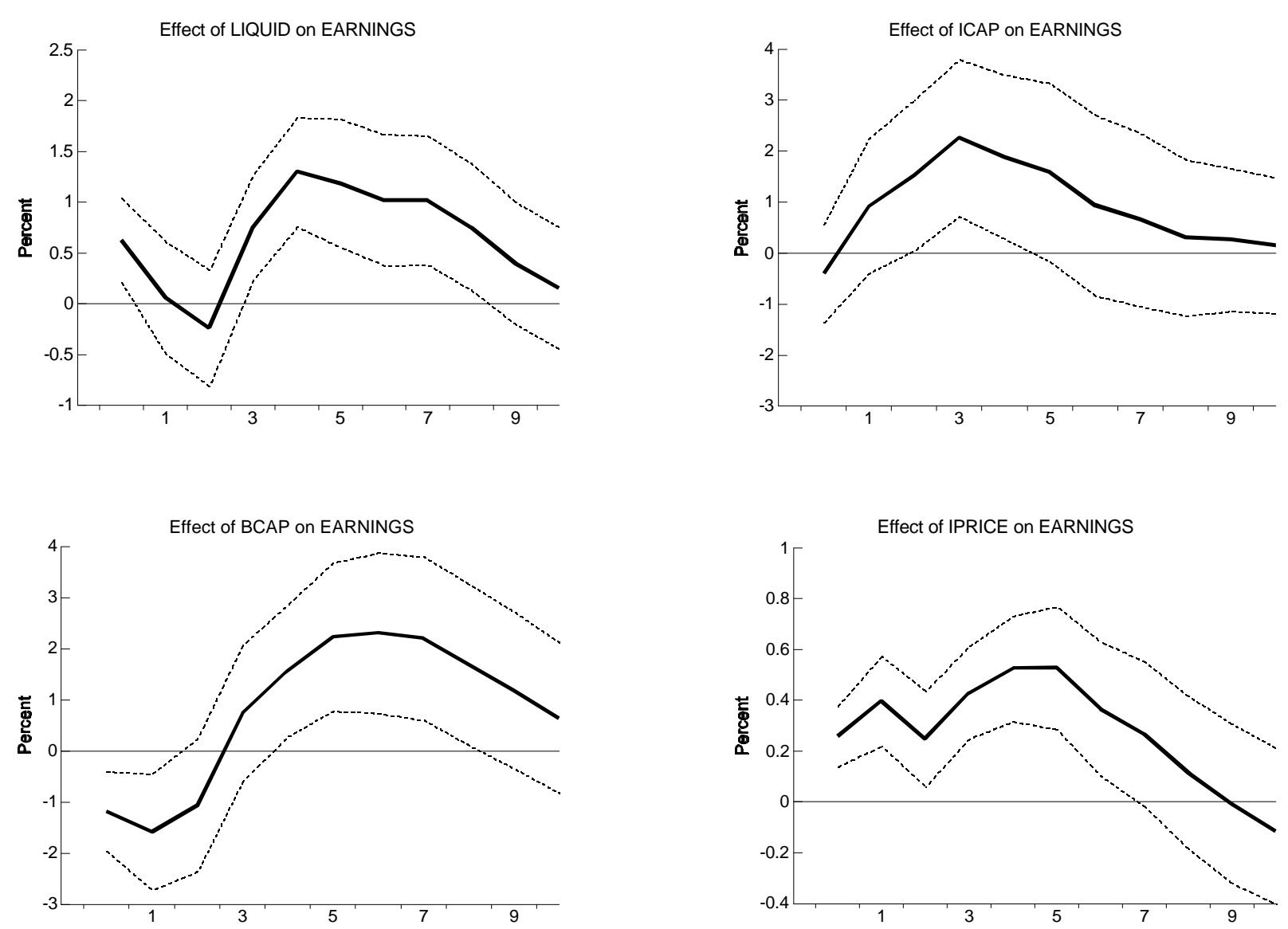

Figure 12. Selected impulse responses from systems with EARN, IPRICE, and a Market Measure

Notes: The impulse responses correspond to systems in Table 3, with the market measure (LIQUID, ICAP, or BCAP) placed first, IPRICE second, and EARN third. The effects of IPRICE on EARN were obtained from the system with LIQUID. See note to Figure 10 for further details.

large. For example, a $\$ 20$ decrease in the average par value of industrial shares from its sample mean of $\$ 220$ (or about a 10 percent increase in LIQUID) is associated with a rise of $\$ 35$ over a four-year period in annual earnings from its sample mean of \$267. A 10 percent increase (about \$5.5 million) in ICAP from its sample mean raises mean annual earnings by more than $\$ 60$ after only three years. A 10 percent increase (about $\$ 5.6$ million) in BCAP from its sample mean raises earnings by about the same amount after five years. The responses of annual earnings to shocks in industrial prices have the same shape and nearly the same magnitude in all three systems. In the system with LIQUID, which is shown in the lower 
right panel of Figure 12, a 10 percent rise in the industrial price index raises earnings by about 5 percent after three years. This considerable response, when combined with the strong Granger-causal role of prices on earnings for all three systems, justifies the inclusion of prices as a measure of general conditions in the industrial sector.

The findings are broadly similar when Howard's (1920) index of annual earnings of cotton manufacturing workers is used as an alternative to Layer's series. In particular, both liquidity and industrial capitalization Granger-cause earnings at the 5 percent level or less, and there is even less evidence of feedback from earnings to the measures of market development. ${ }^{35}$

\section{Conclusion}

Using recently-uncovered primary sources which underlie Joseph Martin's volumes on the history of the Boston stock market, this paper constructed synchronized annual series for prices, total returns and real market capitalizations of traded banks and industrials from 1854 to 1897 . A set of VAR models and the associated impulse responses then indicated that increases in liquidity, as measured by falling average par values of industrials, had positive and statistically significant effects on both prices and the size of the nation's first market in industrial equities. These developments, as well as the deepening of the equity market for banks, are also linked to measurable increases in annual earnings and general industrial performance in New England over the second half of the nineteenth century.

The evidence suggests that emerging financial markets can have strong and relatively rapid effects on the accumulation and allocation of long-term capital and can thereby influence general economic conditions. Central to their effectiveness is confidence among investors that the market can absorb orders to buy and liquidate shares at prices which reflect the intrinsic values of the underlying claims, and that the

\footnotetext{
${ }^{35}$ Given the similarity to the findings reported in Table 3, the full results with Howard's index are not presented here.
} 
availability of the trading mechanism will not be disrupted. New England investors had this assurance, and even innovated by expanding the use of public auctions to improve the efficiency with which prices were determined in a relatively thin market. Overall, the results suggest that occasional setbacks which seem to arise as consequences of rapid market development in modern economies are perhaps best viewed in light of the more optimistic long-run role for equity markets that is made clear by the record of a nation which developed strong financial foundations early in its history. 


\section{REFERENCES}

Atack, Jeremy and Rousseau, Peter L. "Business Activity and the Boston Stock Market, 1835-1869." Explorations in Economic History, April 1999, 36(2).

Barron, Clarence W. and Joseph G. Martin, The Boston Stock Exchange. Boston: Hunt and Bell, 1893.

Baskin, Jonathan Barron. "The Development of Corporate Financial Markets in Britain and the United States, 1600-1914: Overcoming Asymmetric Information." Business History Review, Summer 1988, 62(2), pp. 199237.

Bencivenga, Valerie R., Smith, Bruce D. and Starr, Ross M. "Transactions Costs, Technological Choice, and Endogenous Growth." Journal of Economic Theory, October 1995, 67(1), pp. 153-77.

Boston Stock Exchange. Constitution and By-Laws of the Boston Stock and Exchange Board . Boston: Eastburn's Press, 1852.

Boston Stock Exchange. The Constitution of the Boston Stock Exchange with Rules and Resolutions. Boston: Nathan Sawyer and Son, 1915.

Boston Stock Exchange. The Boston Stock Exchange: Its Inception, Early History, and the Important Contribution It Has Made to Developing New England as a Financial and Investment Centre. Boston: privately printed, 1930.

Burns, Arthur F. and Mitchell, Wesley C. Measuring Business Cycles. New York: National Bureau of Economic Research, 1946.

Copeland, Melvin T. The Cotton Manufacturing Industry in the United States. Cambridge MA: Harvard University Press, 1917.

Cowles, Alfred and Associates. Common Stock Indexes, Cowles Commission for Research in Economics Monograph No. 3. Bloomington, IN: Principia Press, 1938.

Cudd, John M. The Chicopee Manufacturing Company, 1823-1915. Wilmington, DE: Scholarly Resources, 1974. 
Dalzell, Robert F. Enterprising Elite: The Boston Associates and the World They Made. Cambridge, MA: Harvard University Press, 1987.

Davis, Lance E. "The New England Textile Mills and the Capital Markets: A Study of Industrial Borrowing, 1840-1860." Journal of Economic History, March 1960, 20(1), pp. 1-30.

Davis, Lance E. "The Investment Market, 1870-1914: The Evolution of a National Market." Journal of Economic History, September 1965, 25(3), pp. 355-99.

Doan, Thomas A. RATS Users Manual, Version 4. Evanston, IL: Estima.

Fenstermaker, J. Van, Malone, R. Phil and Stansell, Stanley R. "An Analysis of Commercial Bank Common Stock Returns: 1802-97." Applied Economics, June 1988, 20(6), pp. 813-41.

Gallman, Robert. "GNP Less Changes in Inventories, 1860 Prices." Mimeo, June 1965.

Goldsmith, Raymond W. Financial Structure and Development. New Haven: Yale University Press, 1969.

Greenwood, Jeremy and Smith, Bruce D. "Financial Markets in Development, and the Development of Financial Markets." Journal of Economic Dynamics and Control, January 1997, 21(1), pp. 145-81.

Gurley, John G. and Shaw, Edward S. "Financial Aspects of Economic Development." American Economic Review, September 1955, 45(5), pp. 515-38.

Howard, Stanley E. The Movement of Wages in the Cotton Manufacturing Industry of New England Since 1860. Boston: National Council of American Cotton Manufacturers, 1920.

Hansen, Alvin. "Factors Affecting the Trend of Real Earnings." American Economic Review, January 1925, 25(1), pp. 27-42.

James, John A. Money and Capital Markets in Postbellum America. Princeton, NJ: Princeton University Press, 1978.

Johansen, Soren. "Estimation and Hypothesis Testing of Cointegration Vectors in Gaussian Vector Autoregressive Models." Econometrica, November 1991, 59(6), pp. 1551-80.

Knowlton, Evelyn H. Pepperell's Progress. Cambridge, MA: Harvard University Press, 1948. 
Kuznets, Simon S. "Annual Estimates, 1869-1955," technical tables underlying Capital in the American Economy: Its Formation and Financing. Mimeo, National Bureau of Economic Research, 1961.

Kuznets, Simon, Miller, Ann Ratner and Easterlin, Richard A. Population Redistribution and Economic Growth, United States, 1870-1950. Volume II: Analysis of Economic Change. Philadelphia: The American Philosophical Society, 1960.

Lamoreaux, Naomi R., "Banks, Kinship and Economic Development: The New England Case." Journal of Economic History, September 1986, 46(3), pp. 647-67.

Lamoreaux, Naomi R. Insider Lending: Banks, Personal Connections, and Economic Development in Industrial New England. New York: Cambridge University Press, 1994.

Layer, Robert G. Earnings of Cotton Mill Operatives, 1825-1914. Cambridge, MA: Harvard University Press, 1955.

Long, Clarence D. Wages and Earnings in the United States, 1860-1890. Princeton, N.J.: Princeton University Press, 1960.

Lowell, Abbot Lawrence and Lowell, Francis Cabot. The Transfer of Stock in Private Corporations. Boston: Little, Brown, and Company, 1884.

Martin, Joseph G. Twenty-One Years in the Boston Stock Market. Boston: Redding and Company, 1856.

Martin, Joseph G. Seventy-Three Years' History of the Boston Stock Market. Boston: published by the author, 1871.

Martin, Joseph G. A Century of Finance: The Boston Stock and Money Markets, 1798 to 1898. Boston: published by the author, 1898 .

Martin, Joseph G., worksheets to accompany A Century of Finance: The Boston Stock and Money Markets, 1798 to 1898. Boston: published by the author, various years.

McGouldrick, Paul F. New England Textiles in the Nineteenth Century: Profits and Investment. Cambridge, MA: Harvard University Press, 1968. 
McKinnon, Ronald I. Money and Capital in Economic Development. Washington, DC: Brookings Institution, 1973.

Mitchell, Wesley C. Gold, Prices, and Wages Under the Greenbacks. Berkeley: University of California Press, 1908.

Navin, Thomas R. and Sears, Marian V. "The Rise of a Market for Industrial Securities, 1887-1902." Business History Review, 1955, 30(2), pp. 105-38.

Osterwald-Lenum, Michael. "A Note with Fractiles of the Asymptotic Distribution of the Maximum Likelihood Cointegration Rank Test Statistics: Four Cases." Oxford Bulletin of Economics and Statistics, August 1992, 54(3), pp. 461-78.

Phillips, Peter C. B. and Perron, Pierre. "Testing for a Unit Root in Time Series Regression." Biometrika, June 1988, 75, pp. 335-346.

Radelet, Stephen and Sachs, Jeffrey D. "The East Asian Financial Crisis: Diagnosis, Remedies, Prospects" Brookings Papers on Economic Activity, 1998(1), pp. 1-90.

Rousseau, Peter L. "The Permanent Effects of Innovation on Financial Depth: Theory and U.S. Historical Evidence From Unobservable Components Models." Journal of Monetary Economics, October 1998, 42(2), pp. 387-425.

Rousseau, Peter L. and Wachtel, Paul. "Equity Markets and Growth: Cross-Country Evidence on Timing and Outcomes, 1980-1995." Mimeo, Vanderbilt University, September 1998a.

Rousseau, Peter L. and Wachtel Paul. "Financial Intermediation and Economic Performance: Historical Evidence From Five Industrialized Countries." Journal of Money, Credit and Banking, November 1998b, 30(4), pp. 657-78.

Said, Said E. and Dickey, David A. "Testing for Unit Roots in Autoregressive-Moving Average Models of Unknown Order." Biometrika, September 1984, 71, pp. 599-607.

Schumpeter, Joseph. The Theory of Economic Development. Cambridge, MA: Harvard University Press, 1911. 
Shaw, Edward S. Financial Deepening in Economic Development. New York: Oxford University Press 1973.

Sims, Christopher A., Stock, James H. and Watson, Mark W. "Inference in Time Series Models With Some Unit Roots.” Econometrica, January 1990, 58(1), pp. 113-44.

Snowden, Kenneth A. "Historical Returns and Security Market Development, 1872-1925." Explorations in Economic History, October 1990, 27(3), pp. 381-420.

Toda, Hiro Y. and Phillips, Peter C. B. "Vector Autoregressions and Causality." Econometrica, November 1993, 61(6), pp. 1367-93.

Sylla, Richard. "U.S. Securities Markets and the Banking System, 1790-1840." Federal Reserve Bank of St. Louis Review, May/June 1998, 80(3), pp. 83-98.

Sylla, Richard. "Federal Policy, Banking Market Structure, and Capital Mobilization in the United States, 1863-1913." Journal of Economic History, December 1969, 29(4), pp. 657-86.

U.S. Bureau of the Census. Historical Statistics of the United States from Colonial Times to 1970. Washington, DC: Government Printing Office, 1975.

U.S. Comptroller of the Currency. Annual Report of the Comptroller of the Currency. Washington, DC: Government Printing Office, various issues.

Wachtel, Paul and Rousseau, Peter. "Financial Intermediation and Economic Growth: A Historical Comparison of the United States, United Kingdom, and Canada," in Michael D. Bordo and Richard Sylla, eds., Anglo-American Financial Systems: Institutions and Markets in Twentieth-Century. Burr Ridge, IL: Business One Irwin, 1995, pp. 329-81.

The Boston Daily Advertiser, various issues.

The Boston Evening Transcript, various issues.

The Boston Statesman, various issues.

Hunt's Merchants' Magazine, various issues. 
Table A1

Price and Return Indices for Banks and Industrials Traded in the Boston Stock Market, 1854-1897

\begin{tabular}{|c|c|c|c|c|c|c|c|c|}
\hline \multirow[b]{2}{*}{ Year } & \multicolumn{2}{|c|}{$\begin{array}{c}\text { Bank Prices } \\
\text { Weighted By }\end{array}$} & \multicolumn{2}{|c|}{$\begin{array}{l}\text { Bank Returns } \\
\text { Weighted By }\end{array}$} & \multicolumn{2}{|c|}{$\begin{array}{l}\text { Industrial Prices } \\
\text { Weighted By }\end{array}$} & \multicolumn{2}{|c|}{$\begin{array}{l}\text { Industrial Returns } \\
\text { Weighted By }\end{array}$} \\
\hline & $\begin{array}{c}\text { Book } \\
\text { Capital } \\
\end{array}$ & $\begin{array}{c}\text { Market } \\
\text { Value } \\
\end{array}$ & $\begin{array}{c}\text { Book } \\
\text { Capital } \\
\end{array}$ & $\begin{array}{l}\text { Market } \\
\text { Value } \\
\end{array}$ & $\begin{array}{l}\text { Book } \\
\text { Capital } \\
\end{array}$ & $\begin{array}{c}\text { Market } \\
\text { Value }\end{array}$ & $\begin{array}{c}\text { Book } \\
\text { Capital } \\
\end{array}$ & $\begin{array}{c}\text { Market } \\
\text { Value }\end{array}$ \\
\hline 1854 & 100.00 & 100.00 & 3.14 & 3.02 & 100.00 & 100.00 & -8.20 & -6.82 \\
\hline 1855 & 95.16 & 95.14 & 10.90 & 10.69 & 84.17 & 85.44 & 3.18 & 4.06 \\
\hline 1856 & 98.03 & 97.89 & 9.70 & 9.67 & 82.22 & 83.65 & 0.57 & 1.22 \\
\hline 1857 & 100.07 & 99.97 & 1.35 & 1.03 & 77.11 & 78.56 & -19.78 & -14.86 \\
\hline 1858 & 94.10 & 93.77 & 16.35 & 16.34 & 58.15 & 62.55 & 37.57 & 35.24 \\
\hline 1859 & 102.47 & 102.14 & 5.93 & 5.90 & 76.79 & 80.86 & 18.39 & 17.38 \\
\hline 1860 & 101.71 & 101.42 & 3.96 & 3.88 & 84.27 & 87.44 & 12.21 & 11.92 \\
\hline 1861 & 98.93 & 98.60 & -1.30 & -1.39 & 85.59 & 88.60 & 8.94 & 8.44 \\
\hline 1862 & 91.17 & 90.82 & 14.80 & 14.74 & 86.22 & 88.77 & 57.15 & 57.50 \\
\hline 1863 & 98.58 & 98.13 & 10.08 & 9.88 & 119.50 & 122.78 & 5.99 & 8.90 \\
\hline 1864 & 101.78 & 101.19 & 23.66 & 23.33 & 109.64 & 114.91 & 29.41 & 29.37 \\
\hline 1865 & 114.58 & 113.59 & 13.98 & 13.50 & 128.00 & 132.70 & 16.80 & 14.05 \\
\hline 1866 & 108.90 & 107.39 & 17.28 & 17.20 & 134.77 & 135.90 & 10.11 & 10.58 \\
\hline 1867 & 117.59 & 116.02 & 7.15 & 7.04 & 131.94 & 132.90 & -9.88 & -8.85 \\
\hline 1868 & 116.15 & 114.61 & 11.90 & 11.53 & 108.96 & 110.39 & 26.90 & 25.61 \\
\hline 1869 & 119.54 & 117.71 & 8.85 & 8.72 & 126.95 & 126.30 & -7.08 & -5.87 \\
\hline 1870 & 119.91 & 117.98 & 13.53 & 13.48 & 108.34 & 108.32 & -1.32 & -1.25 \\
\hline 1871 & 126.15 & 124.20 & 8.04 & 7.91 & 100.29 & 99.72 & 33.03 & 31.22 \\
\hline 1872 & 126.55 & 124.57 & 4.78 & 4.75 & 122.67 & 119.27 & 9.92 & 10.51 \\
\hline 1873 & 122.97 & 121.08 & 9.16 & 9.07 & 123.45 & 120.12 & -1.20 & 0.27 \\
\hline 1874 & 124.83 & 122.91 & 13.28 & 13.21 & 113.08 & 111.41 & 0.82 & 1.89 \\
\hline 1875 & 132.28 & 130.25 & -1.39 & -1.24 & 106.30 & 105.45 & -6.04 & -4.79 \\
\hline 1876 & 122.37 & 120.75 & 5.76 & 5.60 & 95.06 & 95.03 & 3.19 & 3.99 \\
\hline 1877 & 123.17 & 121.31 & 0.00 & -0.02 & 93.77 & 93.96 & 10.10 & 10.63 \\
\hline 1878 & 117.39 & 115.54 & -6.54 & -6.33 & 97.33 & 97.88 & -5.93 & -4.53 \\
\hline 1879 & 105.24 & 103.73 & 18.14 & 17.67 & 86.46 & 88.14 & 45.68 & 42.33 \\
\hline 1880 & 119.87 & 117.59 & 9.94 & 9.77 & 119.32 & 118.38 & 14.85 & 16.10 \\
\hline 1881 & 125.80 & 123.31 & 2.53 & 2.67 & 128.79 & 128.72 & 12.07 & 11.01 \\
\hline 1882 & 124.01 & 121.70 & 0.70 & 0.75 & 135.37 & 134.03 & -8.93 & -9.82 \\
\hline 1883 & 118.45 & 116.39 & 4.27 & 4.36 & 116.61 & 114.18 & -4.76 & -3.75 \\
\hline 1884 & 118.00 & 116.05 & 2.58 & 2.68 & 105.47 & 104.14 & -6.27 & -5.18 \\
\hline 1885 & 115.46 & 113.70 & 9.64 & 9.23 & 94.82 & 94.41 & 3.08 & 6.74 \\
\hline 1886 & 121.30 & 119.02 & 2.13 & 2.05 & 94.54 & 97.06 & 5.77 & 5.88 \\
\hline 1887 & 118.48 & 116.23 & 5.13 & 5.21 & 96.22 & 98.60 & 4.36 & 4.03 \\
\hline 1888 & 119.05 & 116.91 & 9.18 & 9.05 & 93.79 & 94.99 & 7.54 & 8.05 \\
\hline 1889 & 124.20 & 121.86 & 5.10 & 5.45 & 95.11 & 96.65 & 8.60 & 10.10 \\
\hline 1890 & 125.15 & 123.21 & 6.54 & 6.60 & 97.26 & 100.38 & 4.09 & 4.29 \\
\hline 1891 & 127.81 & 125.93 & -0.19 & -0.86 & 95.86 & 98.97 & 3.93 & 4.07 \\
\hline 1892 & 122.17 & 119.55 & 3.59 & 3.70 & 94.18 & 97.26 & 12.45 & 13.08 \\
\hline 1893 & 121.22 & 118.72 & -4.63 & -4.11 & 99.35 & 102.58 & -4.12 & -6.21 \\
\hline 1894 & 110.53 & 108.78 & 6.78 & 6.98 & 89.88 & 90.45 & 4.09 & 5.04 \\
\hline 1895 & 113.23 & 111.59 & 2.98 & 2.75 & 89.82 & 91.02 & 9.26 & 9.56 \\
\hline 1896 & 111.86 & 109.98 & 0.30 & 0.59 & 93.22 & 94.66 & -2.38 & -2.18 \\
\hline 1897 & 107.40 & 105.88 & 3.63 & 3.71 & 86.95 & 88.31 & -7.39 & -5.35 \\
\hline
\end{tabular}


Table A2

Augmented Dickey-Fuller (ADF) and Phillips-Perron (PP) Statistics for Indicators of Market and Regional Economic Performance, 1854-1897

\begin{tabular}{|c|c|c|c|c|}
\hline & \multicolumn{2}{|c|}{ Levels } & \multicolumn{2}{|c|}{ 1st Differences } \\
\hline & $\mathrm{ADF}$ & $\mathrm{PP}$ & $\mathrm{ADF}$ & $\mathrm{PP}$ \\
\hline $\begin{array}{l}\text { Annual Earnings of Mill Operative } \\
\text { in New England (EARN) }\end{array}$ & -2.61 & -2.75 & $-3.41^{* *}$ & $-4.86^{* *}$ \\
\hline $\begin{array}{l}\text { Market Capitalization in Industrials, } \\
\text { Adjusted for Stock Prices (ICAP) }\end{array}$ & -1.53 & -2.33 & $-3.85^{* *}$ & $-5.22^{* *}$ \\
\hline $\begin{array}{l}\text { Market Capitalization for Banks, } \\
\text { Adjusted for Stock Prices (BCAP) }\end{array}$ & -0.78 & -0.59 & $-3.17^{* *}$ & $-4.49^{* *}$ \\
\hline $\begin{array}{l}\text { Price Index for Industrials } \\
\text { (IPRICE) }\end{array}$ & -2.71 & -2.44 & $-3.64^{* *}$ & $-7.57^{* *}$ \\
\hline $\begin{array}{l}\text { Price Index for Banks } \\
\text { (BPRICE) }\end{array}$ & -0.88 & -1.83 & $-3.41^{* *}$ & $-8.35^{* *}$ \\
\hline $\begin{array}{l}\text { Total Returns for Banks } \\
\text { (BRET) }\end{array}$ & -2.12 & $-5.67^{* *}$ & $-4.79^{* *}$ & $-12.57^{*}$ \\
\hline $\begin{array}{l}\text { Shares per } \$ \text { of Traded Industrial } \\
\text { Capital (LIQUID) }\end{array}$ & -1.97 & -2.64 & $-3.88^{* *}$ & $-7.02^{* *}$ \\
\hline
\end{tabular}

All variables are in logs. The test specifications include constant and trend for the levels variables (with the exception of BRET which includes a constant only) and constant only for first differences. The ADF regressions use three lags. * and ** denote rejections of the unit root hypothesis at the $10 \%$ and $5 \%$ levels respectively. 
Table A3

Johansen Test Statistics for Cointegration, 1854-1897

\begin{tabular}{lcccccc}
\hline \hline & \multicolumn{2}{c}{ Trace $\left(\eta_{\mathrm{r}}\right)$} & \multicolumn{2}{c}{ Max. Eigen. $\left(\zeta_{\mathrm{r}}\right)$} & \multicolumn{2}{c}{ Coint. Vector } \\
System & $\mathrm{r}=0$ & $\mathrm{r} \leq 1$ & $\mathrm{r}=0$ & $\mathrm{r} \leq 1$ & $\mathrm{r} \leq 2$ & $\alpha_{1}=1$ \\
\hline ICAP, BCAP, and LIQUID (K=2) & $27.46^{*}$ & 9.23 & 17.22 & 6.31 & 2.92 & $1,9.409,-10.868$ \\
& & & & & & \\
& & & & & & \\
IPRICE, BRET, and LIQUID with & $43.55^{* * *}$ & 22.25 & 21.30 & 15.38 & 6.87 & $1,-0.866,-0.092, .008$ \\
trend (K=3) & & & & & & \\
EARN, IPRICE, and LIQUID & $39.85^{* *}$ & $14.14^{*}$ & $25.71^{* *}$ & 8.31 & & $1,-0.757,-0,563$ \\
(K=3) & & & & & & \\
EARN, IPRICE, and BCAP (K=3) & $36.76^{* *}$ & $18.33^{* *}$ & $18.63^{*}$ & $12.65^{*}$ & $5.68^{* *}$ & $1,-1.525,-0.205$ \\
EARN, IPRICE, and ICAP (K=3) & $33.63^{* *}$ & 9.66 & $23.97^{* *}$ & 5.62 & 4.04 & $1,-1.292,-0.561$ \\
\hline
\end{tabular}

Each system includes the variables listed in the left column. $\mathrm{K}$ is the lag at which the levels terms enter the test regressions. The columns labeled $r=0$ test a null hypothesis of no cointegration, while the $r \leq 1(r \leq 2)$ columns test a null of at most one (two) cointegrating vectors. * and ** denote rejections of the null at the $10 \%$ and $5 \%$ levels respectively, with appropriate critical values from Osterwald-Lenum (1992), Tables 1 and 2*. 